\title{
Prolonged Occupation and Exploitation of Natural
}

\section{Resources}

\section{A Focus on Natural Gas off the Coast of Northern Cyprus}

\author{
Emilia Pabian \\ Grotius Centre for International Legal Studies, Leiden University, Leiden, \\ The Netherlands \\ empabian@gmail.com
}

\begin{abstract}
During recent years, natural gas reserves have been located off the coast of Cyprus and their possible exploitation has drawn the attention of Turkey, which has been in occupation of Northern Cyprus for decades. This contribution explores whether the law of occupation could provide a legal basis for the exploitation by Turkey of Northern Cyprus' natural gas, specifically considering the prolonged nature of the occupation. It argues that Turkey is obliged to comply with the restrictive rules governing the use of natural resources in occupied territories. Furthermore, this contribution discusses the argument that during prolonged occupations an occupying power should be granted more leeway in imposing wider ranging initiatives to prevent the local population's developmental stagnation, including more extensive natural resource exploitation. However, this contribution argues that granting such leeway has the potential to entrench the authority of the occupant into a state of permanency under the guise of legitimacy.
\end{abstract}

\section{Keywords}

international humanitarian law - law of occupation - occupied territories - natural resources - Turkey - Northern Cyprus - prolonged occupation 


\section{Introduction and Background}

The law of occupation governs the administration of occupied territories like that of Northern Cyprus which has been occupied by Turkey for decades. ${ }^{1}$ This legal regime includes specific provisions regulating the exploitation and management of natural resources located in such territories. ${ }^{2}$ In recent years, possibly lucrative natural gas reserves have been discovered off the coast of Cyprus and the potential exploitation of such resources has ignited Turkey's interest. ${ }^{3}$ In light thereof, the present contribution aims to determine whether the law of occupation could provide a legal basis for Turkey's claims to the hydrocarbons located off the shore of the occupied territory, specifically considering the prolonged nature of Turkey's occupation of Northern Cyprus and the unique challenges posed thereby. ${ }^{4}$

In July 1974, Turkish military forces invaded Cyprus, responding to the overthrow of the president of the newly independent Republic of Cyprus. ${ }^{5}$ The invasion was preceded by inter-communal tensions between the island's Greek Cypriot majority and Turkish Cypriot minority, ${ }^{6}$ stemming from, inter alia, a constitutional amendment which effectively disallowed Turkish Cypriots from sharing in the State's government. ${ }^{7}$ Pursuant thereto, the Turkish military occupied the northern third of the island, dividing it into the Turkish Cypriot community in the north and the Greek Cypriot community in the south, separated by the United Nations (UN) controlled buffer zone. ${ }^{8}$ Over 200 ooo people were

1 Loizidouv Turkey EchR 1996-IV [56]; Susan Power, 'Occupying the Continental Shelf? - A Note Considering the Status of the Continental Shelf Delimitation Agreement Concluded between Turkey and the TRNC During the Belligerent Occupation of Northern Cyprus' (2014) 9 The Irish Yearbook of International Law 91, 94; See discussion in 2.2.

2 Particularly, Hague Convention (Iv) Respecting the Laws and Customs of War on Land and its Annex: Regulations Concerning the Laws and Customs of War on Land (adopted 18 October 1907, entered into force 26 January 1910) 205 CTS 277 (HR), arts 53 and 55 .

3 Hasan Selim Özertem, 'Turkish Foreign Policy and the Energy Bonanza in the Eastern Mediterranean' (2016) 18 Journal of Balkan and Near Eastern Studies 361, 361-362.

4 International Committee of The Red Cross, Report by Tristan Ferraro, 'Expert Meeting: Occupation and Other Forms of Administration of Foreign Territory' (2O12) (ICRC) 72.

5 Eyal Benvenisti, The International Law Occupation (2nd edn, OUP 2012) 191-192; F Stephen Larrabee, 'Greek-Turkish Relations in an Era of Regional and Global Change' (2012) 12 Southeast European and Black Sea Studies 471, 472.

6 Vasileios Karakasis, "Energy Security and the Cyprus Question: "Securitization" of Energy in the Eastern Mediterranean' (2015) 27 Politikon: IAPSS Political Science Journal 5, 28.

7 Power (n 1) 93; Benvenisti (n 5) 192.

8 John Sitilides, 'The Modern Geopolitics of the Cyprus Question' (2014) 25 Mediterranean Quarterly 77, 78; Murat Metin Hakki, 'Property Wars in Cyprus: The Turkish Position According to International Law' (2010) 3 Ankara Bar Review 43, 44; Karakasis (n 6). 
subsequently transferred both to and from Northern Cyprus, ${ }^{9}$ where Turkey has maintained a presence of approximately 30 ooo troops..$^{10}$ Additionally, Turkey transferred significant numbers of Turkish nationals from its mainland to Northern Cyprus. ${ }^{11}$ In 1983, the Turkish Cypriots declared the independence of the Turkish Republic of Northern Cyprus ('TRNC'), ${ }^{12}$ which is recognised solely by Turkey and is dependent on its economy. ${ }^{13}$ The Greek Cypriot administration in the south, the Republic of Cyprus, has been internationally recognised as the only legitimate representative of Cyprus and has been a member of the European Union (EU) since 2004. ${ }^{14}$ To date, despite numerous attempts at negotiated settlement, ${ }^{15}$ Turkey maintains its presence in Northern Cyprus, which is generally considered to constitute an illegal occupation and has persistently been condemned. ${ }^{16}$

In recent years, the discovery of natural gas reserves in the seabed off the coast of Cyprus has sparked renewed interest in the so-called 'Cyprus Issue.'. ${ }^{17}$ What was optimistically foreseen as a catalyst for cooperation and a motive for finding a solution to the conflict, has in fact exacerbated it. ${ }^{18}$ Steps taken by the Republic of Cyprus towards the development of offshore gas reserves, including proclaiming an exclusive economic zone (EEZ), ${ }^{19}$ concluding EEZ

9 Benvenisti ( $\mathrm{n}_{5}$ ) 192.

10 ibid; Larrabee (n 5) 475; Karakasis (n 6).

$11 \quad$ Karakasis (n 6); Benvenisti (n 5) 193; Christos Ioannides, 'Turkish Controlled Cyprus: The Consolidation of Occupation' in Eugene Rossides and Van Coufoudakis (eds), The United States and Cyprus: Double Standards and the Rule of Law (American Hellenic Institute Foundation 2002) 114 and 123-124.

12 Özertem (n 3$)_{361 .}$

13 Benvenisti (n 5) 192-193; Hakki (n 8); Ioannides (n 11) 114-115.

14 Sitilides (n 8) 79; Özertem (n 3) 368; Halil Rahman Basaran, 'The Cyprus Question, International Law and European Law: An Assessment' (2018) 28 Transnational Law and Contemporary Problems 1, 5 .

15 Larrabee (n 5$) 475$.

16 Benvenisti (n 5) 193-194; Ilias Kouskouvelis, "The Problem with Turkey's "Zero Problems"' (2013) 20 Middle East Quarterly 47, 48; Karakasis (n 6) 28-29; Power (n 1).

17 Sitilides (n 8) 77; Özertem (n 3); James Stocker, 'No EEz Solution: The Politics of Oil and Gas in the Eastern Mediterranean' (2012) 66 The Middle East Journal 579, 579.

18 Ioannis Grigoriadis, 'Energy Discoveries in the Eastern Mediterranean: Conflict or Cooperation?' (2014) 21 Middle East Policy 124, 126; Constantine Levoyannis, 'Eastern Mediterranean Gas: The Energy Union's Next Frontier' (2016) 6 European Energy Journal 57, 57; Tolga Demiryol, 'Between Security and Prosperity: Turkey and the Prospect of Energy Cooperation in the Eastern Mediterranean' (2019) 20 Turkish Studies 442, 442-443; Karakasis (n 6) 6.

19 Theodore Kariotis, 'Hydrocarbons and the Law of the Sea in the Eastern Mediterranean: Implications for Cyprus, Greece, and Turkey' (2011) 22 Mediterranean Quarterly 45, 45; Demiryol (n 18) 451; Karakasis (n 6) 15 and 19. 
delimitation agreements with coastal States in the region, ${ }^{20}$ and awarding exploration licences to private energy companies, ${ }^{21}$ have prompted Turkey to send its own naval, exploration and drilling ships into the contested waters and to conclude a continental shelf delimitation agreement with the 'TRNC', theoretically permitting Turkey to drill for gas off the island's coast. ${ }^{22}$ These actions have been widely criticised by the international community and have led to the imposition of economic sanctions on Turkey by the EU. ${ }^{23}$

Notwithstanding, Turkey - which does not recognise the Republic of Cyprus alleges that the Republic of Cyprus cannot take unilateral action in relation to any hydrocarbon reserves without considering the alleged rights of Turkish Cypriots over the island's maritime areas, and, accordingly, their alleged right to share in the revenue from future gas development. ${ }^{24}$ Turkey has vowed to continue its drilling efforts to protect these alleged rights, ${ }^{25}$ thereby extending 'the military occupation of Cyprus to cover [its] territorial waters and other sea waters.' ${ }^{26}$ In May 2019, Turkish drillship 'Fatih' began drilling at 36.6 nautical miles from Cyprus' west coast. ${ }^{27}$ Furthermore, a second ship 'Yavuz' was sent

20 Agreements were concluded with Egypt, Lebanon, and Israel; Kariotis (n 19) 47; The International Institute for Strategic Studies, 'Gas Finds Complicate Eastern Mediterranean Security' (2013) 19 Strategic Comments xiii, xiv; Demiryol (n 18) 444 and 451.

21 Including ExxonMobil, Qatar Petroleum, Total, ENI, Kogas and Noble Energy; Özertem (n 3) 363; Karakasis (n 6) 20; Gaurav Sharma, 'Turkey Won't 'Back Down' in Pursuit of Natural Gas in Eastern Mediterranean' Forbes (8 October 2019) <https://www.forbes.com/sites/ gauravsharma/2019/10/o8/turkey-wont-back-down-in-pursuit-ofnatural-gas-in-eastern-med iterranean/\#1f $f_{2} f_{5963 a b}>$ accessed 21 November 2019; Ioakeim Ampartzidis, 'The NeoOttoman Turkish Lebensraum Agenda Towards the Cyprus-Cypriot Eez: A Constructivist Approach of a State as Superorganism' (2019) 16 In Depth: Cyprus Center for European and International Affairs 22, 22.

22 Grigoriadis (n 18) 128; The International Institute for Strategic Studies (n 20); Demiryol (n 18) 452-453; Stocker (n 17) 585; Power (n 1) 91.

23 Associated Press, 'EU Slaps Sanctions on Turkey over Gas Drilling Off Cyprus' Voice of America (16 July 2019) <https://www.voanews.com/europe/eu-slaps-sanctions-turkey-overgas-drilling-cyprus $>$ accessed 2 September 2019; Sharma (n 21).

24 Grigoriadis (n 18) 127-128; Demiryol (n 18) 452; Karakasis (n 6) 22-23; Matina Stevis-Gridneff, 'E.U. Punishes Turkey for Gas Drilling Off Cyprus Coast' The New York Times (15 July 2019) <https://www.nytimes.com/2019/o7/15/world/europe/eu-turkey-cyprus.html> accessed 2 September 2019.

25 Helena Smith, 'Turkey rejects claims it is drilling illegally for gas off Cyprus' The Guardian (11 July 2019) <https://www.theguardian.com/world/2019/jul/11/turkey-rejects-claims-drillingillegally-gas-off-cyprus $>$ accessed 2 September 2019.

26 Giorgos Kentas, 'Realpolitik in Europe and Eastern Mediterranean' (2019) 16 In Depth: Cyprus Center for European and International Affairs 7, 13.

27 Nicholas Ioannides, 'A Legal Appraisal of the Turkish Drilling Activities in the Continental Shelf/EEZ of Cyprus' (2019) 16 In Depth: Cyprus Center for European and International Affairs 15, 15 . 
to the territorial waters south of the Karpas Peninsula which forms part of the occupied territory. ${ }^{28}$

Opposing arguments of Turkey and the Republic of Cyprus have primarily focused on sovereignty in their respective maritime zones, with Turkey claiming parts of the Republic of Cyprus' EEZ and continental shelf, either on behalf of the 'TRNC' or in its own name. ${ }^{29} \mathrm{~A}$ substantial volume of scholarship has been dedicated to their competing claims under the law of the sea, ${ }^{30}$ without delving much into the law of occupation. This could be attributed to the fact that Turkey does not acknowledge itself as occupant of Northern Cyprus. ${ }^{31}$ However, the law of occupation could prove useful in determining the potential validity of Turkey's claims to the maritime areas extending from the occupied area.

It has long been accepted that Turkey is in fact in occupation of Northern Cyprus. ${ }^{32}$ Consequently, it is argued that the law of occupation, as a subset of international humanitarian law ( $\mathrm{IHL}$ ), is applicable to this state of affairs and Turkey is thus obliged to comply with its obligations thereunder. However, Turkey has justified its presence in Northern Cyprus with reference to the 1960 Treaty of Guarantee, in terms of which each party was granted the 'right to take action with the sole aim of re-establishing the state of affairs created by the present Treaty'. ${ }^{33}$ Furthermore, Turkey has argued that its actions were in protection of the alleged right to self-determination of the island's Turkish Cypriot minority. ${ }^{34}$ Nonetheless, Turkey's actions have been declared to be contrary to international law and its withdrawal from Northern Cyprus has been repeatedly demanded..$^{35}$

28 ibid.

29 Demiryol (n 18) 444; Stocker (n 17) 583; Karakasis (n 6) 15; Michalis Kontos, 'Recent Developments on Cyprus: Re-Assessing the Agenda of Public Discourse' (2019) 16 In Depth: Cyprus Center for European and International Affairs 4, 5 .

30 See, eg: Kariotis (n 19); Grigoriadis (n 18); Demiryol (n 18); Stocker (n 17); Karakasis (n 6).

31 Vaios Koutroulis, 'The Application of International Humanitarian Law and International Human Rights Law in Situation of Prolonged Occupation: Only a Matter of Time?' (2012) 94 International Review of the Red Cross 165, 171.

$3^{2}$ Loizidou (n 1); Kouskouvelis (n 16); Benvenisti (n 5) 193; Power (n 1).

33 Treaty of Guarantee (signed 16 August 196o, entered into force 16 August 196o), art IV; Benvenisti (n 5) 167 and 192; Enrico Milano, Unlawful Territorial Situations in International Law: Reconciling Effectiveness, Legality and Legitimacy (Martinus Nijhoff 2006) 142-143.

34 Hakki (n 8); Benvenisti (n 5) 168-169; Ioannides (n 11) 126.

35 See United Nations General Assembly Resolution (UNGA Res) 3212 (XXIX) (1 November 1974); UNGA Res 3395 (XXX) (20 November 1975); UNGA Res 33/15 (9 November 1978); UNGA Res 34/30 (20 November 1979); UNGA Res 37/253 (13 May 1983); United National Security Council Resolution (UNSC Res) 541 (18 November 1983); UNSC Res 550 (11 May 1984); Karakasis (n 6) 29; Benvenisti (n 5) 193. 
According to the law of occupation, which is predominantly found in the Regulations annexed to the 1907 Hague Convention IV (Hague Regulations), ${ }^{36}$ the 1949 Geneva Convention IV (GCIV), ${ }^{37}$ and the 1977 Additional Protocol I to the Geneva Conventions (AP I), ${ }^{38}$ once it has been established that a territory is under occupation by a foreign State ${ }^{39}$ such State acquires certain rights and obligations relating to the administration of the occupied territory, ${ }^{40}$ including the exploitation and management of natural resources. ${ }^{41}$ Therefore, the law of occupation could assist in justifying Turkey's natural gas claims in Northern Cyprus. However, the uncharacteristically prolonged nature of Turkey's occupation complicates the application of the law of occupation, which is especially evident when applying the relevant provisions governing natural resources.

The law of occupation is premised on the idea that occupations are meant to be temporary, ${ }^{42}$ during which a balance must be struck between preserving the territorial State's institutions, providing for the security needs of the occupant, and protecting the welfare of the population..$^{43}$ Notwithstanding, this has not prevented States from invading and occupying others for decades at a time, some classic examples being Israel's occupation of the Palestinian territories, ${ }^{44}$ Morocco's occupation of Western Sahara, ${ }^{45}$ and the situation at hand Turkey's occupation of Northern Cyprus, which has continued for almost 46 years. ${ }^{46}$ Due to the possibility of developmental stagnation as a result of the obligation to maintain existing institutions in the occupied territory, the

$36 \quad \mathrm{HR}$.

37 Geneva Convention Relative to the Protection of Civilian Persons in Time of War (adopted 12 August 1949, entered into force 21 October 1950) 75 UNTS 287 (GCIV).

38 Protocol Additional to the Geneva Conventions of 12 August 1949, and relating to the Protection of Victims of International Armed Conflicts (adopted 8 June 1977, entered into force 7 December 1978) 1125 UNTS 3 (AP I); Benvenisti (n 5) 11; Iain Scobbie, 'Natural Resources and Belligerent Occupation: Mutation Through Permanent Sovereignty' in Stephen Bowden (ed), Human Rights, Self-Determination and Political Change in the Occupied Palestinian Territories (Routledge 2011) 224.

HR, art 42; Marco Longobardo, The Use of Armed Force in Occupied Territory (CUP 2018) $28-29$.

40 Generally under HR, art 43 and GCIV, art 64; Benvenisti (n 5) 68-69.

41 Particularly HR, arts 53 and 55 .

42 Longobardo (n 39) 5o; Benvenisti (n 5) 6; ICRC (n 4) 72.

43 Longobardo (n 39) 53-54 and 58; Philip Spoerri, 'The Law of Occupation' in Andrew Clapham and Paola Gaeta (eds), The Oxford Handbook of International Law in Armed Conflict (OUP 2015) 186.

44 Longobardo (n 39) 10-11 and 52; Koutroulis (n 31) 168.

45 Longobardo (n 39) 12-13; Koutroulis (n 31 ).

46 Koutroulis $(\mathrm{n} 31)$. 
adequacy of the law of occupation to govern modern-day prolonged occupations has been questioned. ${ }^{47}$

As aforesaid, the aim of the present contribution is to determine whether Turkey could rely on the law of occupation to justify its natural gas claims detailed above, specifically considering the occupation's prolonged character. In doing so, Section 2 will break down the general principles and purpose of the law of occupation and set out the requirements for triggering its application. Section 3 will cover the specific provisions relating to the exploitation of natural resources in occupied territories, including the rights and duties of the occupant and restrictions placed thereon. Section 4 will discuss the consequences of non-compliance and outline options for enforcement. Finally, Section 5 will aim to determine whether the fact that an occupation is long-term affects the application of the law of occupation in general, and specifically, those provisions relating to natural resource exploitation.

\section{Rationale, General Principles and Application of the Law of Occupation}

Prior to discussing the provisions relevant to the exploitation of natural resources, it is necessary to focus on the law of occupation in general, which informs the interpretation and application of the specific provisions as aforesaid. This Section will examine the underlying aims of this concept of international law, together with the principles which characterise it as a distinct regime. Furthermore, the requirements for the existence of an occupation will be discussed, the fulfilment of which is a prerequisite for the application of the law of occupation. ${ }^{48}$

\subsection{General Principles and Underlying Rationale of the Law of Occupation}

The law of occupation is centred on certain basic principles which reflect the rationale for the existence of this legal regime ${ }^{49}$ namely, to provide for the administration of the occupied territory by the occupying power for the occupation's duration, in anticipation of the sovereign's return to power or an

\footnotetext{
47 ICRC (n 4); Spoerri (n 43) 186-187.

48 Spoerri (n 43) 187.

49 Aeyal Gross, The Writing on the Wall: Rethinking the International Law of Occupation (CUP 2017) 18.
} 
alternative peaceful solution. ${ }^{50}$ This aim is largely reflected in Article 43 of the Hague Regulations, which states that:

[t]he authority of the legitimate power having in fact passed into the hands of the occupant, the latter shall take all the measures in his power to restore, and ensure, as far as possible, public order and safety, while respecting, unless absolutely prevented, the laws in force in the country. ${ }^{51}$

An occupying power is thus obliged to preserve the existing institutions and continue to apply the ousted sovereign's laws during the occupation. ${ }^{52}$ The sovereign title to the territory remains with the ousted government, although, pursuant to the development of the concept of human and peoples' rights, such sovereignty arguably lies with the population under occupation..$^{53}$ The sovereignty principle ensures that foreign territory cannot be annexed by an occupying power due to the prohibition of forceful acquisition of territory. ${ }^{54}$

The Hague Regulations, having entered into force in the early twentieth century, focused on the relationship between the occupant and the sovereign State. ${ }^{55}$ Limited authority over the territory was granted to maintain public order without conferring title on the occupant or changing pre-occupation institutions, unless necessary for security purposes. ${ }^{56} \mathrm{GCIV}$, which was concluded pursuant to the Second World War, and the later development of human rights and the principle of self-determination, shifted the focus to protecting the interests of the local population, ${ }^{57}$ and the principles underlying the law of occupation shifted simultaneously. 58

According to Article 43 of the Hague Regulations quoted above, which is considered to reflect customary international law, ${ }^{59}$ the occupant has the

ibid; Prosecutor v Naletilic and Martinovic (Judgement) ICTY-98-34-T (31 March 2003) [214]; Eyal Benvenisti, 'The Origins of the Concept of Belligerent Occupation' (2008) 26 Law and History Review 621, 621-622; Longobardo (n 39) 40-41.

$51 \quad$ HR, art 43.

$5^{2} \quad$ Gross (n 49) 22; Spoerri (n 43) 185 .

53 Benvenisti (n 5) 1; Gross (n 49); Longobardo (n 39) 25.

54 Benvenisti (n 5 ) 1; Laurie Blank and Gregory Noone, International Law and Armed Conflict: Fundamental Principles and Contemporary Challenges in the Law of War (2nd edn, Wolters Kluwer 2019) 169; Gross (n 49) 21 and 24-25.

Benvenisti (n 5) 69; Pal Wrange, 'Self-Determination, Occupation and the Authority to Exploit Natural Resources: Trajectories from Four European Judgments on Western Sahara' (2019) 52 Israel Law Review 3, 4-5.

56 Benvenisti (n 5) 70-71; Wrange (n 55$) 8$.

57 Benvenisti (n 5) 69-70; Wrange (n 55) 5 .

$5^{8}$ Benvenisti (n 5) 7, 11-12, and 72; Gross (n 49) 26.

59 Benvenisti (n 5 ) 69. 
power and duty to ensure public order and safety or civil life in the occupied territory. ${ }^{60}$ However, the occupant is not given a blank cheque to impose new laws. ${ }^{61}$ The maintenance of the status quo, also known as the 'conservationist principle', restricts the occupant's powers, ${ }^{62}$ but is nevertheless not absolute. ${ }^{63}$ The meaning of the phrase 'unless absolutely prevented' has developed from denoting mere military necessity, ${ }^{64}$ and the occupant is now considered entitled to modify the laws and institutions of the occupied territory should such modifications be generally 'necessary', ${ }^{65}$ which necessity incorporates the welfare of the population. ${ }^{66}$ Thus, the occupant is permitted to administer the occupied territory, while considering its own security interests, the population's interests and the maintenance of the status quo as far as possible. ${ }^{67}$

Article 64 of GCIV complements the aforementioned Article 43, granting the occupant the right to implement:

provisions which are essential to enable the Occupying Power to fulfil its obligations under the present Convention, to maintain the orderly government of the territory, and to ensure the security of the Occupying Power, of the members and property of the occupying forces or administration $[\ldots] .68$

The occupant is thereby permitted to impose its own laws and policies on the population. ${ }^{69}$ However, this is restricted to measures benefitting the local population of the occupied territory and not the occupant's own interests. ${ }^{70}$ Accordingly, a delicate balance must be struck between providing for the

6o The French text refers to 'civil life', but its English counterpart refers to 'safety'. The French text is argued to be correct; ibid 68 and 77; Gross (n 49) 17; Longobardo (n 39) 54.

$61 \quad$ Blank and Noone (n 54) 187; Spoerri (n 43) 192.

62 Longobardo (n 39) 58.

63 Benvenisti (n 5) 90-91; Yutaka Arai-Takahashi, 'Preoccupied with Occupation: Critical Examinations of the Historical Development of the Law of Occupation' (2012) 94 International Review of the Red Cross $51,53-54$ and 71 .

64 Benvenisti ( $\mathrm{n}_{5}$ ) 91.

65 ibid 92; Arai-Takahashi (n 63) 54; Spoerri (n 43) 194-195.

66 Benvenisti ( $\mathrm{n}_{5}$ ) 92.

67 Spoerri (n 43) 185-186; Gross (n 49) 30; Tassilo Singer, 'Occupation of Sea Territory: Requirements for Military Authority and Comparison to Art. 43 of the Hague Convention IV' in Jörg Schildknecht and others (eds), Operational Law in International Straits and Current Maritime Security Challenges (Springer 2018) 256.

68 GCIV, art 64; Gross (n 49) 31; Arai-Takahashi (n 63) 67-68.

69 Benvenisti (n 5) 73; Arai-Takahashi (n 63) 68.

$70 \quad$ Longobardo (n 39) 57; Spoerri (n 43). 
population and maintaining daily life,${ }^{71}$ preserving existing institutions, and providing for the occupant's security needs. ${ }^{72}$ Evidently, the law of occupation is equally 'permissive' and 'prohibitive. ${ }^{73}$ The move towards increased protection of and provision for the interests of the population is welcome, however, it also enables abuse by the occupant, whereby it can become legitimately entitled to alter the status quo under the guise of 'public welfare. ${ }^{74}$

The law of occupation is founded upon the principle of temporality. ${ }^{75}$ It was originally contemplated that occupations would not extend for long periods, ${ }^{76}$ and that this legal regime would 'fill the gap' during conflict while the sovereign lacked effective territorial control. ${ }^{77}$ An example of a provision reflecting this principle is Article 55 of the Hague Regulations which permits the occupying power to simply manage and protect public immovable property, without obtaining ownership thereof. ${ }^{78}$ Notwithstanding, the law of occupation fails to stipulate any time-limit for occupations and, therefore, theoretically, occupations can continue indefinitely as this is not prohibited. ${ }^{79}$ This has been experienced in practice and has created debate regarding whether the law of occupation is appropriate to govern such situations, ${ }^{80}$ as the society in the occupied territory needs to develop economically and in cultural, social and political contexts. ${ }^{81}$ Therefore, prolonged occupations have raised questions whether the rights of administration detailed above should be expanded for the benefit of the population. ${ }^{82}$

\subsection{Scope of Application of the Law of Occupation}

Stepping back, one can only apply the abovementioned principles and the various rules governing occupations once it has been established that the particular territory has been occupied. ${ }^{83}$ Article 42 of the Hague Regulations provides that:

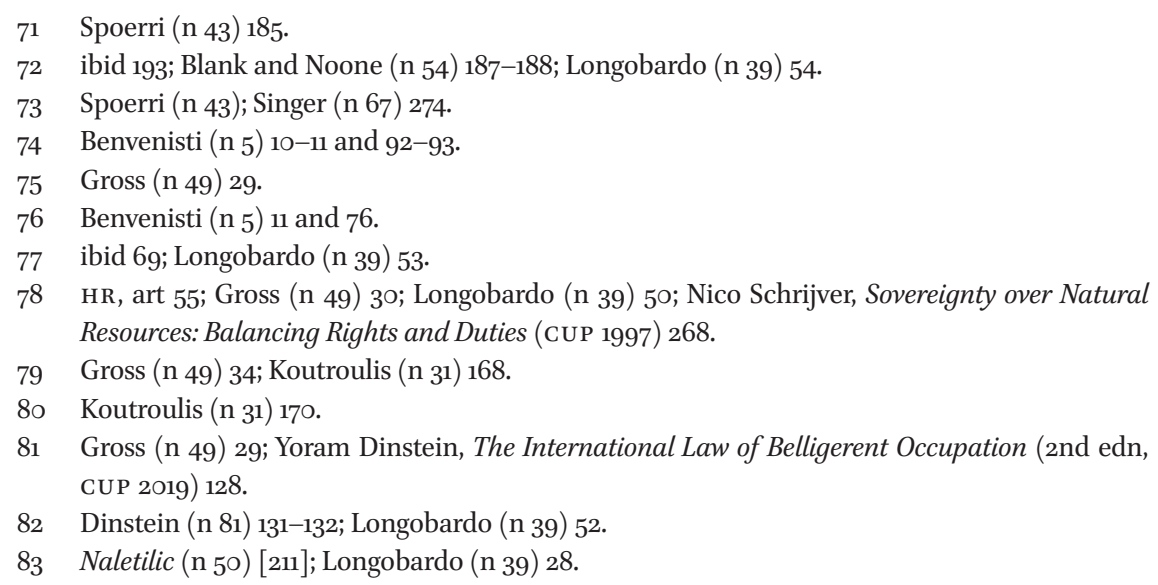


[t]erritory is considered occupied when it is actually placed under the authority of the hostile army. The occupation extends only to the territory where such authority has been established and can be exercised. ${ }^{84}$

Article 42 , reflecting customary international law, ${ }^{85}$ remains the pivotal yardstick for determining whether a territory is subject to an occupation. ${ }^{86}$ It has been widely argued that the application of Article 42 is a purely factual determination. ${ }^{87}$ Thus, once the authority of a foreign military force has been factually demonstrated, this alone triggers the application of the law of occupation. ${ }^{88}$ Notwithstanding, Gross argues that the normative context of any occupation should form part of the analysis, otherwise there lies a risk of abuse of the situation by an occupying power whereby it can use the law of occupation in its favour to further any ulterior motives it may have. ${ }^{89}$ This aspect will be discussed further in Section 5 .

The test contained in Article 42 of the Hague Regulations has been referred to as the test of 'effective control' 90 and has been further split into three separate requirements which give more substance to the codified provision: (1) a foreign military presence; (2) the ability of the foreign forces to exercise authority over the territory in the place of the ousted sovereign; and (3) the lack of consent of such sovereign. ${ }^{91}$

\subsubsection{Effective Control Over Territory}

The effective control test, also known as the 'Von Glahn formula', is aptly summarised by Von Glahn as follows:

as long as the territory as a whole is in the power and under the control of the occupant and as long as the latter has the ability to make [their] will felt everywhere in the territory within a reasonable time, military occupation exists from a legal point of view. ${ }^{92}$

84 HR, art 42.

85 Legal Consequences of the Construction of a Wall in the Occupied Palestinian Territory (Advisory Opinion) [2004] ICJ Rep 136 [78]; Case Concerning Armed Activities on the Territory of the Congo (Democratic Republic of the Congo v Uganda) (Judgement) [2005] ICJ Rep 168 [172].

86 Naletilic (n 5o) [217]; Spoerri (n 43) 188; Blank and Noone (n 54) 171.

87 Benvenisti (n 5) 4, 43 and 51; Longobardo (n 39) 29 and 34; Blank and Noone (n 54).

88 Longobardo (n 39) 29; Milano (n 33) 90.

89 Gross (n 49) 20, 23 and 35-38.

$90 \quad$ Longobardo (n 39) 35; Benvenisti (n 5) 47; Blank and Noone (n 54) 171.

91 Longobardo (n 39) 30; Benvenisti (n 5) 67; Spoerri (n 43) 188.

92 Gerhard von Glahn, The Occupation of Enemy Territory: A Commentary on the Law and Practice of Belligerent Occupation (University of Minnesota Press 1957) 29. 
Accordingly, a prerequisite for an occupation is the exercise of authority over a foreign territory and the inability of the ousted sovereign to exercise such authority any longer. ${ }^{93}$ This is coupled with the lack of consent of such ousted sovereign. ${ }^{94}$ The tribunal in Naletilic provided useful guidelines to determine whether there is a sufficient degree of authority exercised by the occupant to render a territory occupied. These include, inter alia, the occupying power being in a position to replace the sovereign's authority with that of its own; the sovereign's incapability to function publicly in the territory; the occupying power having sufficient forces present or the capacity to send forces to exert its authority within a reasonable time; and the existence of a temporary administration by the occupant. ${ }^{95}$ Nevertheless, the exercise of actual authority over the population is arguably not a requirement as such. ${ }^{96}$ Otherwise an occupant which is unwilling to assume its obligations could refrain from establishing its authority over the people or could install a puppet regime, ${ }^{97}$ creating a gap in protection of the population. ${ }^{98}$ An occupant does not have to have every piece of land within the territory under its control. ${ }^{99}$ It merely must be capable of enforcing its authority by sending troops to certain areas. ${ }^{100}$ Therefore, the level of authority required depends on the circumstances, including the number of inhabitants in any given region. ${ }^{101}$

In practice, like in Northern Cyprus, ${ }^{102}$ occupants have been reluctant to recognise their status as occupying powers due to the obligations involved and the negative connotation attached thereto. ${ }^{103}$ However, any lack of acknowledgement by an occupant of its status does not detract from the actual legal position. ${ }^{104}$ Accordingly, it is argued that Turkey is indeed in occupation of

\footnotetext{
93 Spoerri (n 43) 188; Longobardo (n 39) 30; Singer (n 67) 263.

94 Benvenisti (n 5) 67; Spoerri (n 43) 19o; Longobardo (n 39) 30.

$95 \quad$ Naletilic (n 5o) [217]; Longobardo (n 39) 36.

96 Longobardo (n 39) 55. See, however, Sargsyan v Azerbaijan App no 40167/o6 (ECtHR, 16 June 2015) [144], wherein it was held that actual authority and the presence of troops on the ground is in fact required.

97 ibid 30 and 41; Benvenisti (n 5) 85; Singer (n 67) 264.

98 Case Concerning Armed Activities on the Territory of the Congo (Democratic Republic of the Congo v Uganda) [2005] ICJ Rep 168 (Separate Opinion of Judge Koojimans) [49]; Benvenisti (n 5) 50; Spoerri (n 43) 190.

$99 \quad$ Naletilic (n 50$)$ [218].

$100 \quad$ Benvenisti (n 5) 51; Spoerri (n 43) 189; Longobardo (n 39) 36.

101 Benvenisti (n 5) 51; Spoerri (n 43) 189.

102 Benvenisti (n 5) 167.

103 ibid 44 and 68; Spoerri (n 43) 184; Longobardo (n 39) 34.

104 Blank and Noone (n 54); Milano (n 33) 156-157; Arai-Takahashi (n 63) 69.
} 
Northern Cyprus. ${ }^{105}$ This has been confirmed by the European Court of Human Rights (ECtHR) on various occasions. ${ }^{106}$ The presence of thousands of Turkish troops on the territory is undisputed, ${ }^{107}$ which troops have been 'stationed throughout the whole of the occupied area of Northern Cyprus, which is constantly patrolled and has checkpoints on all main lines of communication.' ${ }^{108}$ Turkey has substituted the previous regime with its own administration which it alone considers to constitute an independent State. ${ }^{109}$ However, the establishment of a seemingly autonomous puppet regime does not affect the fact that the 'TRNC' is wholly dependent on Turkey's economy and is effectively controlled by it, and that the Turkish military plays a decisive role in the 'TRNC's administration. ${ }^{110}$ The Constitutional Court of the 'TRNC' itself has applied the law of occupation to the appropriation of property in Northern Cyprus by Turkey as an occupant. ${ }^{111}$ Therefore, there is little doubt that Turkey is occupying Northern Cyprus, which renders it liable to comply with its obligations under the law of occupation. ${ }^{112}$

\subsubsection{Effect of the '(Il-)legality' of the Occupation}

Turkey's occupation of Northern Cyprus has been labelled 'illegal' by various actors in the international community. ${ }^{113}$ However, the illegality of an occupation merely refers to the illegal manner in which the occupant intervened in the territory of the occupied State, and not to the illegality of the occupation as such. ${ }^{114}$ The occupation of Northern Cyprus and its attempted secession was brought about in contravention of the prohibition of the use of force against the territorial integrity of another State found in Article 2(4) of the 1945 Charter of the United Nations. ${ }^{115}$ Annexation no longer constitutes a legitimate

\footnotetext{
$105 \quad$ Longobardo (n 39) 12; Power (n 1 ) 92.

106 Loizidou (n 1) [54] and [56]; Cyprus v Turkey EC HR 2001-IV [77]; Demopoulos and Others v Turkey App no 46113/99 (ECtHR, 1 March 2010) [94].

107 Ioannides (n 11) 123; Benvenisti (n 5) 193; Sitilides (n 8) 83.

108 Loizidou (n 1) [16].

109 Longobardo (n 39) 12.

$110 \quad$ ibid 56; Cyprus (n 106); Benvenisti (n 5) 193-194; Ioannides (n 11) 123; Cansu Akgün, 'The Case of TRNC in the context of Recognition of States under International Law' (2010) 1 Ankara Bar Review 7, 14.

111 National Unity Party (Ulusal Birlik Partisi) v TRNC Assembly of the Republic (KKTC Cumhuriyet Meclisi) ILDC 499 (TCC 2006) [Fl]; Power (n 1) 95-96.

112 Power (n 1).

113 Demopoulos (n 106); Benvenisti (n 5) 193-194; Milano (n 33) 143; Longobardo (n 39 ) 12.

114 Spoerri (n 43) 184; Benvenisti (n 5) 16-17; Dinstein (n 81) 3 .

115 Charter of the United Nations (adopted 25 June 1945, entered into force 24 October 1945) 1 UNTS XVI, art 2(4); UnSC Res 541 (18 November 1983); UnsC Res $55^{\circ}$ (11 May
} 
method of territorial acquisition and any such forceful acquisition is unlawful, ${ }^{116}$ can constitute an act of aggression, ${ }^{117}$ and cannot be recognised under international law. ${ }^{118}$ The principle that territorial sovereignty does not pass to an occupant precludes the annexation of the occupied territory, ${ }^{119}$ which is further refined in Article 47 of GCIV which provides that any purported annexation or change made by an occupant does not affect the rights of protected persons under GCIV. ${ }^{120}$ The illegality of the use of force in bringing about an occupation, as part of the jus ad bellum, does not influence the applicability of the law of occupation, as part of the jus in bello. ${ }^{121}$ Accordingly, the occupant is nevertheless bound to comply with its administrative, humanitarian and other duties under the law of occupation and the illegality of its prior actions has no bearing thereon nor on the territory's status as occupied. ${ }^{122}$

\subsubsection{Effect of the Occupant's Motive}

Similarly, any justification put forward by an occupant for its actions also does not affect the applicability of the law of occupation. ${ }^{123}$ Accordingly, it is argued that Turkey's attempted justification of its invasion of Cyprus, based on protecting Turkish Cypriots and their alleged right to self-determination, ${ }^{124}$ does not influence Turkey's rights and corresponding obligations as an occupying power. It may be difficult to accurately identify the genuine motive of an occupant, ${ }^{125}$ however, although Turkey defended its occupation with reference to the protection of Turkish Cypriots, ${ }^{126}$ it was confirmed in 2000 by the

1984); Parliamentary Assembly of the Council of Europe (PACE), 'Situation in Cyprus' Recommendation 974 (1983) (24 November 1983); PACE, 'Situation in Cyprus' Resolution 816 (1984) (21 March 1984); Longobardo (n 39) 12; Benvenisti (n 5) 194.

Declaration on Principles of International Law Concerning Friendly Relations and Co-operation among States in Accordance with the Charter of the United Nations, UNGA Res 2625 (xxv) (24 October 1970), art 1(11); Longobardo (n 39) 25-26; Benvenisti (n 5) 17; Stefano Silingardi, 'Belligerent Occupation and it's Discontents: On the Relationship between International Human Rights Law and Belligerent Occupation's Law' (2019) Global Jurist 1.

Definition of Aggression, UnGA Res 3314 (XXIX) (14 December 1974), art 3(a); Benvenisti (n

5) 168; Singer (n 67).

118 Akgün (n 110) 16; Milano (n 33) 97.

119 Milano (n 33) 96.

120 GCIV, art 47; Gross (n 49) 24; Power (n 1) 97-98.

$121 \quad$ Spoerri (n 43) 184; Gross (n 49) 25; Benvenisti (n 5 ) 198.

122 Dinstein (n 81) 3-4; Milano (n 33) 90 and 97; Longobardo (n 39) 29.

123 Congo (n 85) [173]; Benvenisti (n 5) 202.

124 Benvenisti (n 5) 168-169 and 199; Ioannides (n 11) 126; Akgün (n 110) 16.

125 Benvenisti (n 5$) 169$.

$126 \quad \operatorname{Akgün}(\mathrm{n} 110) 10$. 
Turkish State Minister that even if there were no Turkish Cypriots left, Turkey would continue to intervene in Cyprus. ${ }^{127}$ Furthermore, the Turkish President stated in 2011 that Turkey had interests in Cyprus of a strategic nature which went beyond the protection of Turkish Cypriots. ${ }^{128}$ Notwithstanding, as mentioned, any such motives have no bearing on the status of Northern Cyprus as occupied.

\subsection{Occupation of Maritime Territory}

The law of occupation, when codified, was geared towards the occupation of land territory, and does not explicitly provide for the occupation of maritime territory. ${ }^{129}$ However, if the law of occupation is to assist in providing a basis for Turkey's natural gas claims, one must determine whether or not this body of law can be applied to maritime territory, and if so, to what extent.

Although the Hague Regulations specifically refer to the 'Laws and Customs of War on Land', 130 they also contain provisions directly relating to an occupant's actions at sea. ${ }^{131}$ These include Article 53 regarding the seizure of appliances for news transmission or transport at sea, ${ }^{132}$ and Article 54 regarding the seizure and destruction of submarine cables. ${ }^{133}$ Furthermore, GCIV contains no provisions restricting its application to land territory. ${ }^{134}$ Additionally, although non-binding, ${ }^{135}$ Article 88 of the 1913 Oxford Manual of the Laws of Naval War (Oxford Manual) provides that:

[o]ccupation of maritime territory, that is of gulfs, bays, roadsteads, ports and territorial waters, exists only when there is an occupation of continental territory, by either a naval or a military force. The occupation, in that case, is subject to the laws and usages of war on land. ${ }^{136}$

\footnotetext{
127 Ioannides (n 11$) 118$.

128 Sitilides (n 8) 82.

129 Singer (n 67) 255; Jeffrey Smith, 'International Law and Western Sahara's Maritime Area' (2019) 50 Ocean Development \& International Law 117, 129.

130 Allan Gerson, 'Off-Shore Oil Exploration by a Belligerent Occupant: The Gulf of Suez Dispute' (1977) 71 American Journal of International Law 725, 728; Singer (n 67) 258.

131 Marco Longobardo, 'The Occupation of Maritime Territory under International Humanitarian Law' (2019) 95 International Law Studies 322, 330.

$132 \quad$ HR, art 53; Power (n 1) 107; Singer (n 67) 258.

133 HR, art 54; Power (n 1) 107; Longobardo (n 131).

134 Singer (n 67) 261; Longobardo (n 131) 331 .

135 Singer ( $\mathrm{n} 67) 257$.

136 Oxford Manual of Naval Law, Adopted by the Institute of International Law (1913) in D Schindler and J Toman, The Laws of Armed Conflicts: A Collection of Conventions,
} 
Therefore, it appears that the occupation of sea territory was not excluded from the law of occupation. ${ }^{137}$ Although most activities covered by the law of occupation can only take place ashore, ${ }^{138}$ certain aspects such as natural resource management can also find relevance at sea. ${ }^{139}$ If the rules governing the occupant's authority merely applied until the coastline, this would create a legal gap in respect of the sea territory over which the ousted sovereign can no longer exercise control. ${ }^{140}$ Therefore, the word 'territory' in Article 42 of the Hague Regulations should be interpreted flexibly to include sea territory. ${ }^{141}$ This is consistent with the object and purpose of the Hague Regulations, aiming to protect the sovereignty of the ousted sovereign while permitting the occupant to control its territory in the interim. ${ }^{142}$ Additionally, the practice of Israel in asserting that parts of the Gulf of Suez were occupied reflects the possibility of occupation of maritime territory. ${ }^{143}$ Such territory can be considered occupied if the land territory from which it acquires its status is occupied, ${ }^{144}$ and if there is sufficient military authority exerted within the sea territory. ${ }^{145}$ Thus, if the occupant has sufficient naval forces to make its authority known within a reasonable period, the sea territory will also be effectively controlled and thus considered occupied. ${ }^{146}$

Regarding the scope of application of the law of occupation to sea territory, there is general acceptance of its application to territorial waters, consistent with the aforesaid provision of the Oxford Manual, ${ }^{147}$ which waters extend up to 12 nautical miles according to the 1982 United Nations Convention on the Law of the Sea (UNCLOS). ${ }^{148}$ It has been argued that the extents of the relevant

\footnotetext{
Resolutions, and other Documents (4th edn, Brill 2004) 1135, art 88 (emphasis added); ibid 26o; Longobardo (n 131) 337 . force 16 November 1994) 1833 UNTS 3 (UNCLOS), art 3; Singer (n 67) 271-272; Longobardo (n 131) 346.
} 
maritime zones reflected in UNCLOS, namely, the territorial sea, ${ }^{149}$ continental shelf, ${ }^{150}$ and EEZ, ${ }^{151}$ are considered to be customary international law and are binding on non-State-parties, ${ }^{152}$ which would include Turkey. ${ }^{153}$ It is less clear whether the occupation extends to the EEZ or the continental shelf, rights to which were not recognised when the Oxford Manual was adopted. ${ }^{154}$ Longobardo argues that the EEz and continental shelf cannot be occupied since the coastal State does not hold full territorial sovereignty in respect thereof. ${ }^{155}$ Notwithstanding, many argue that these zones are indeed capable of occupation. ${ }^{156}$ In regard to the EEZ, extending up to 200 nautical miles, ${ }^{157}$ the ousted sovereign's rights to natural resource exploration or exploitation can be temporarily exercised by the occupant. ${ }^{158}$ Furthermore, the continental shelf, being the natural prolongation of the land territory and comprising the seabed and subsoil, ${ }^{159}$ is also capable of being utilised by the occupant, to the extent of the rights held by the sovereign. ${ }^{160}$ It has been argued that in order to discharge its duties to provide for the population and maintain public order, an occupant is even required to administer the occupied maritime territories, let alone entitled. ${ }^{161}$

Consequently, should Turkey's naval forces exercise sufficient authority over the territorial waters, EEZ or continental shelf adjacent to the land territory of Northern Cyprus, Turkey could be entitled to exploit the hydrocarbon reserves located in such zones. Whether or not such actions would be lawful will be discussed in the following Section.

\footnotetext{
149 Territorial and Maritime Dispute (Nicaragua v Colombia) (Judgment) [2012] ICJ Rep 624 [177].

150 Continental Shelf (Libyan Arab Jamahiriya/Malta) (Judgement) [1985] ICJ Rep 13 [77]; Nicaragua (n 149) [118].

$151 \quad$ Libyan Arab Jamahiriya (n 150) [34].

$15^{2}$ J Ashley Roach, 'Today's Customary International Law of the Sea' (2014) 45 Ocean Development \& International Law 239, 242-243, 246 and 248.

153 Power (n 1) 102-103.

154 Dinstein (n 81) 56; Singer (n 67) 272.

155 Longobardo (n 131) 347-348.

156 Dinstein (n 81) 56; Clagett and Johnson (n 147); Singer (n 67) 273-274.

157 UNCLOS, arts $56-57$.

158 Singer (n 67) 273; Smith (n 129) 126.

159 UNCLOS, art 76(1); Dinstein (n 81) 56.

16o UnClos, art 77; Power (n 1) 105-106; Singer (n 67) 274.

161 Benvenisti (n 5$) 55$.
} 


\section{The Law of Occupation Regulating the Exploitation of Natural Resources}

The law of occupation contains specific provisions regarding property located within an occupied territory, ${ }^{162}$ which regulate the rights and limitations to the exploitation of natural resources. ${ }^{163}$ These limitations reveal that an occupant is not entitled to deal with natural resources as it pleases. ${ }^{164}$ This Section shall discuss these provisions and apply them to the situation in Northern Cyprus.

\subsection{Limits to the Exploitation of Natural Resources and the Concept of Usufruct}

Since the occupation of foreign territory does not confer sovereignty upon the occupant, ${ }^{165}$ the occupant does not acquire title to such territory's natural resources, ${ }^{166}$ and may only administer them according to the law of occupation. ${ }^{167}$ The provisions relevant to natural resource exploitation are primarily contained in Articles 53 and 55 of the Hague Regulations, ${ }^{168}$ since natural resources are generally categorised as public property, ${ }^{169}$ although this remains subject to the national laws in force prior to the occupation. ${ }^{170}$ Furthermore, natural resources still in situ are classified as immovable property and are governed by Article $55 \cdot{ }^{171}$ However, if already extracted before the occupation, they will constitute movable property and be regulated by Article 53 which allows the taking possession and use thereof for 'military operations.' ${ }^{172} \mathrm{~A}$ particular

162 Marco Longobardo, 'State Responsibility for International Humanitarian Law Violations by Private Actors in Occupied Territories and the Exploitation of Natural Resources' (2016) 63 Netherlands International Law Review 251, 254; Schrijver (n 78).

163 Gerson (n 130) 729; Gamal Abouali, 'Natural Resources under Occupation: The Status of Palestinian Water Under International Law' (1998) 1o Pace International Law Review 411, 467; Daniella Dam-de Jong, International Law and Governance of Natural Resources in Conflict and Post-Conflict Situations (EM Meijers Instituut 2013) 217.

Iain Scobbie, 'Natural Resources and Belligerent Occupation: Perspectives From International Humanitarian and Human Rights Law' in Susan Akram, Michael Dumper, Michael Lynk and Iain Scobbie (eds), International Law and the Israeli-Palestinian Conflict: A Rights Based Approach to Middle East Peace (Martinus Nijhoff 1997) 229; Scobbie (n 38) 233.

165 Power (n 1$) 100$.

166 Schrijver (n 78) 268; Scobbie (n 38) 227; Abouali (n 163).

167 Benvenisti (n 5$) 81$.

168 Scobbie (n 164) 233.

169 ibid; Clagett and Johnson (n 147) 562.

170 Longobardo (n 162).

171 ibid; Clagett and Johnson (n 147) 562-563; Dam-de Jong (n 163).

172 HR, art 53; Scobbie (n 164) 234; Dinstein (n 81) 235; Schrijver (n 78). 
prohibition is contained in Article 147 of GCIV, which disallows the 'extensive destruction and appropriation of property, not justified by military necessity and carried out unlawfully and wantonly', and classifies such actions as grave breaches. ${ }^{173}$ Additionally, Article 47 of the Hague Regulations and Article 33 of GCIV, which are applicable to both public and private property and also natural resources, prohibit the pillaging thereof,, ${ }^{174}$ namely, appropriation for personal benefit. ${ }^{175}$

This subsection will focus on publicly owned natural resources which are yet to be extracted or discovered due to the specific circumstances applicable to the natural gas in the Eastern Mediterranean, and therefore, Article 55 of the Hague Regulations is of particular relevance. Article 55 provides as follows:

The occupying State shall be regarded only as administrator and usufructuary of public buildings, real estate, forests, and agricultural estates belonging to the hostile State, and situated in the occupied country. It must safeguard the capital of these properties, and administer them in accordance with the rules of usufruct. ${ }^{176}$

Although relatively vague, this provision demonstrates that the use of natural resources by the occupying power is not prohibited as such. ${ }^{177}$ However, such use is restricted by the rules of the principle of usufruct. $^{178}$ Although this term is not defined, ${ }^{179}$ it is generally accepted that it refers to the right to use and obtain the fruits of the property without diminishing or destroying it. ${ }^{180}$ This is bolstered by the duty to 'safeguard the capital' of the property which forbids its depletion. ${ }^{181}$ Article 55 complements the occupant's obligations under Article 43 of the Hague Regulations, in that public immovable property must be preserved and returned to the ousted sovereign in a condition comparable

\footnotetext{
173 GCIV, art 147; Gerson (n 130) 729.

174 HR, art 47; GCIV, art 33; Prosecutor $v$ Delalić and Others (Judgement) ICTY-96-21-T (16 November 1998) [59o]; Longobardo (n 162) 255; Sylvain Vité, "The Interrelation of the Law of Occupation and Economic, Social and Cultural Rights: The Examples of Food, Health and Property' (2008) 9o International Review of the Red Cross 629, 646.

175 Dam-de Jong (n 163) 219.

$176 \quad \mathrm{HR}$, art 55 (emphasis added).

177 Longobardo (n 162) 255.

178 Dinstein (n 81) 231; Clagett and Johnson (n 147) 564; Scobbie (n 38) 233.

179 Clagett and Johnson (n 147) 564.

180 Scobbie (n 164) 233-234; Gerson (n 130) 730; Longobardo (n 131) $35^{2}$.

181 Schrijver (n 78); Ben Saul, 'The Status of Western Sahara as Occupied Territory Under International Humanitarian Law and the Exploitation of Natural Resources' (2015) 27 Global Change, Peace \& Security 301, 316.
} 
to that at the start of the occupation. ${ }^{182}$ This includes property located in the maritime zones of the occupied territory. ${ }^{183}$ Therefore, when applying Article 55 to natural resources, it is clear that an occupant may indeed exploit such resources and reap the benefits thereof, ${ }^{184}$ however, this may not result in their exhaustion, disposal, or destruction. ${ }^{185}$

\subsection{Exploitation of Non-Renewable Natural Resources}

The exploitation of non-renewable resources such as oil or natural gas encounters obstacles since such resources are naturally exhaustible. ${ }^{186}$ There have been numerous debates regarding whether such resources may be used by the occupant at all. ${ }^{187}$ It appears that although some authors reject this possibility, ${ }^{188}$ most contemporary opinions gravitate towards allowing non-renewable resource exploitation provided that it is sustainable, not excessive, and does not completely deplete such resources. ${ }^{189}$ This seems to be the correct approach considering the occupant's obligations to maintain orderly life and ensure that the population is provided for, and further considering the changing nature of occupations, requiring increased involvement of the occupying power to ensure effective administration.

\subsection{New Natural Resource Exploration and Development}

Another linked issue is whether an occupant may search for and tap newly discovered natural resources which were not being exploited by the ousted sovereign before the occupation. ${ }^{190}$ This was explored in relation to the sinking of new oil wells by Israel in the continental shelf of Sinai and the Gulf of Suez in the 1970 , ${ }^{191}$ and it was argued that the development of new oil fields was not permitted. ${ }^{192}$ Thus, an occupant was arguably only entitled to continue

\footnotetext{
182 Longobardo (n 39) 6o; Smith (n 129) 132.

183 Singer (n 67) 283; Power (n 1$) 106$ and 108.

184 In Abouali (n 163) 469, Abouali argues that an occupant has no right to the fruits of public immovable property, however, this is inconsistent with the concept of usufruct.

185 Benvenisti (n 5) 82; Vité (n 174) 647; Scobbie (n 38) 233-234.

186 Scobbie (n 164) 234; Schrijver (n 78); Vité (n 174) 648.

187 Schrijver (n 78); Dam-de Jong (n 163) 227.

188 Clagett and Johnson (n 147) 575; Smith (n 129) 132.

189 Dinstein (n 81) 235; Gerson (n 130) 731; Schrijver (n 78) 269; Dam-de Jong (n 163) 228 and $381-382$.

$190 \quad$ Dinstein (n 81) 235; Singer (n 67) 284.

191 Dinstein (n 81) 235.

192 Scobbie (n 164) 234 referring to US Department of State, 'Department of State Memorandum of Law on Israel's Right to Develop New Oil Fields in Sinai and the Gulf of Suez' (1977) 16 International Legal Materials 733, 733-739.
} 
exploiting existing oil fields at the 'normal pre-occupation rate'193 due to its obligation to preserve the capital of the non-renewable resource. ${ }^{194}$ Therefore, any exploitation would entail 'over-exploitation' and consequently be unlawful. ${ }^{195}$ Such approach appears to coincide with the occupant's obligations under Article 43 to maintain the status quo unless absolutely prevented. ${ }^{196}$ Additionally, Article 7 of GCIV provides that "[n]o special agreement shall adversely affect the situation of protected persons [...] nor restrict the rights which it confers upon them, ${ }^{\prime}{ }^{197}$ and Article 47, which expands thereon, ${ }^{198}$ prevents the local population from being deprived of protection due to changes introduced or agreements concluded by the occupant. ${ }^{199}$ These provisions are supplementary to the property related provisions of the Hague Regulations. ${ }^{200}$ Under this interpretation, Turkey would be forbidden from issuing licences to companies for natural gas exploration or drilling in Northern Cypriot waters. ${ }^{201}$ The conclusion of a continental shelf delimitation agreement like that entered into between the 'TRNC' and Turkey in 2011 would also be precluded. ${ }^{202}$

Notwithstanding, Gerson argues that the rationale for the prohibition of prospecting and opening new mines under the concept of usufruct, being the damage caused to the territory, is irrelevant to maritime hydrocarbon exploration. ${ }^{203}$ Furthermore, Paust contends that it would be better to consider the occupant as entitled to 'reasonable' use of such resources, even if their capital becomes depleted. ${ }^{204}$ Additionally, some argue that if the added value of newly exploited resources is directed towards the local population, such exploitation can be 'assessed more generously'. ${ }^{205}$

A third argument specifically relating to natural resources found in the continental shelf refers to Article 2 of the 1958 Convention on the Continental

\footnotetext{
193 ibid; Scobbie (n 38$) 246$.

194 Clagett and Johnson (n 147) 574-577; Saul (n 181) 317.

195 Vité (n 174) 647.

196 Scobbie (n 38) 243-244.

197 GCIV, art 7.

198 Power (n 1) 100.

199 GCIV, art 47; Longobardo (n 131) 353-354.

200 Power (n 1$) 100$.

201 ibid 108; See discussion in relation to Western Sahara in Saul (n 181) 319; In Scobbie (n 38) $245^{-246}$, Scobbie argues that an occupant is not entitled to conclude agreements regarding natural resource exploitation.

202 Power (n 1) 91 and 108-109.

203 Gerson (n 130) 732.

204 Jordan Paust, 'Oil Exploitation in Occupied Territory: Sharpening the Focus on Appropriate Legal Standards' (1979) 1 Houston Journal of International Law 147, 148-149.

205 Singer (n 67) 284; Yoram Dinstein, The International Law of Belligerent Occupation (cu P 2009) 216.
} 
Shelf which is considered to constitute customary international law. ${ }^{206}$ This provision grants exclusive sovereign rights to the coastal State for exploring and exploiting such resources, which rights remain unaffected by any occupation. ${ }^{207}$ Therefore, it has been argued that since an occupant never becomes the holder of such sovereign rights, it is not even permitted to continue existing resource exploitation let alone commence with new exploitation. ${ }^{208}$

Accordingly, there appears to be no clear consensus on whether newly discovered or untapped resources may be exploited by an occupant, although opinions seem to gravitate towards a negative answer. Regardless, a critical issue remains, in that any natural resource exploitation, whether in continuation of the sovereign's activities or exploitation of new discoveries, may only be for the benefit of the population of the occupied territory or the occupying forces. $^{209}$

\subsection{Permitted Purpose of Natural Resource Exploitation}

Any natural resource exploitation must relate to provision for the needs of the local population or occupying forces, ${ }^{210}$ or otherwise 'finance the expenses connected with the occupation'.211 Such exploitation thus cannot further other objectives of the occupant, ${ }^{212}$ such as its own economic interests. ${ }^{213}$ Therefore, any use of natural resources not for the local population's benefit or the occupant's 'imperative military needs', ${ }^{214}$ will be unlawful. ${ }^{215}$ An occupant's obligation to maintain public order and civil life logically requires financial means, consequently, natural resource exploitation can provide such means provided it only benefits the population. ${ }^{216}$

206 Convention on the Continental Shelf (adopted 29 April 1958, entered into force 10 June 1964) 499 UNTS 311 (CCS), art 2; North Sea Continental Shelf (Federal Republic of Germany/ Denmark, Federal Republic of Germany/Netherlands) (Judgement) [1969] ICJ Rep 3 [63]. CCS, art 2(1)-(3).

208 Scobbie (n 38$) 25$ o.

209 Benvenisti (n 5$) 82$.

210 Jeffrey Smith, 'The Taking of the Sahara: The Role of Natural Resources in the Continuing Occupation of Western Sahara' (2015) 27 Global Change, Peace \& Security 263, 273; Longobardo (n 131) 352; Singer (n 67) 283.

211 Vité (n 174) 648; Dam-de Jong (n 163) 227.

212 Benvenisti (n 5 ) 82; Spoerri (n 43).

213 Scobbie (n 164); Paust (n 204) 149; Saul (n 181) 317.

214 Saul (n 181) 319.

215 ibid 318; Congo (n 85) [249]; Eugene Kontorovich, 'Economic Dealings with Occupied Territories' (2015) 53 Columbia Journal of Transnational Law 584, 603.

216 Wrange (n 55) 10. 
Notwithstanding, the purpose of resource exploitation may in reality diverge from what the occupant alleges, and without any oversight mechanism it may be difficult to identify its genuine objectives. ${ }^{217}$ Nonetheless, evidence regarding the destination of profits and their later expenditure, although not usually publicly available, can be useful in determining who the beneficiaries really are. ${ }^{218}$ Indeed, Benvenisti argues that his analysis indicates 'that social decisions taken and implemented in occupied territories were never incompatible with outcomes sought by occupants. ${ }^{219}$ In regard to Northern Cyprus, any revenue from Turkey's natural gas exploration is, at the time of writing, yet to be produced. However, it could be discerned from pronouncements made by Turkish officials, ${ }^{220}$ that Turkey's activities in the Eastern Mediterranean may be motivated by economic and security imperatives. ${ }^{221}$ Such motives would be irreconcilable with the aim of directing revenue for the exclusive benefit of the Northern Cypriot inhabitants.

\subsection{Transfer of Settlers and Its Impact on Permitted Natural Resource Exploitation}

An aspect further complicating the situation in Northern Cyprus is that the civilian population largely consists of Turkish settlers, transferred through 'state sponsored migration'222 from the Turkish mainland. ${ }^{223}$ Subsequent to Turkey's invasion, thousands of Greek Cypriots moved to the recognised south, while Turkish Cypriots moved to the occupied north. ${ }^{224}$ However, to date, large numbers of these Turkish Cypriots have emigrated, ${ }^{225}$ leaving Northern Cyprus primarily occupied by the settlers and military forces. ${ }^{226}$ Therefore, if Turkey attempted to justify its natural gas exploitation on the ground of benefitting the local population, keeping with Turkey's alleged protection of Turkish Cypriots' rights to such gas, a counter argument would be that the current population is not the same as that when the occupation began. Therefore, it is no

\footnotetext{
217 Benvenisti (n 5) 79.

218 Saul (n 181) 320.

219 Benvenisti (n 5$) 11$.

220 Ioannides (n 11) 127, referring to comments by the Deputy Prime Minister in 2002.

221 ibid 117.

222 Benvenisti (n 5 ) 193.

223 Kontorovich (n 215) 592 and 616; Sandra Hummelbrunner, 'Contextualisation of Psagot in light of other CJEU Case Law on Occupied Territories' (2019) 4 European Papers 779, 789; Ioannides (n 11) 123-124.

224 Karakasis (n 6); Benvenisti (n 5) 192; Ioannides (n 11) 120.

225 Karakasis (n 6).

226 Ioannides (n 11) 125-127.
} 
longer practicable for Turkey to benefit the original population by exploiting such resources. ${ }^{227}$

Additionally, the transfer of an occupant's own civilian population to the occupied territory is prohibited under Article 49(6) of GCIV, ${ }^{228}$ thus any resource exploitation for the benefit of such civilians is unlawful. 229 Accordingly, the exploitation of resources to benefit the Turkish settlers transferred to Northern Cyprus in contravention of Article 49(6) would not be permitted. Furthermore, Article 4 of GCIV provides, inter alia, that persons who find themselves in the hands of an occupying power of which they are not nationals qualify as 'protected persons. ${ }^{230}$ Such persons are entitled to have their interests protected by the occupant. ${ }^{231}$ This does not apply to the occupant's own nationals, and thus such persons (like the Turkish settlers) are not entitled to benefit from GCIV and Article 43 of the Hague Regulations must accordingly be construed to benefit only the original local population. ${ }^{232}$

\section{Consequences of Unlawful Natural Resource Exploitation in an Occupied Territory}

After setting the parameters within which natural resources may be utilised, the consequences of violation of the relevant restrictions must be addressed. It is uncontroversial that the breach of an international obligation invokes the international responsibility of a State. ${ }^{233}$ However, natural resource exploitation which contravenes the law of occupation entails the liability of the occupying power as well as that of other participating actors. ${ }^{234}$ Accordingly, this Section will discuss the consequences of breach by the occupant and outline the potential liability of other actors involved, such as third States and international organisations. In doing so, this Section will broadly evaluate possible options for enforcement. Although beyond the scope of this contribution,

\footnotetext{
227 Karakasis (n 6) 23; See discussion regarding Western Sahara in Smith (n 210) 279-280.

228 GCIV, art 49(6); Wall (n 85) [120]; See discussion of Israeli settlements in Palestine in Hummelbrunner (n 223) 783 .

229 Saul (n 181) 317 and 320.

230 GCIV, art 4.

$231 \quad$ Longobardo (n 39) 57.

232 ibid.

233 ILC, 'Draft Articles on Responsibility of States for Internationally Wrongful Acts with Commentaries' in 'Report of the International Law Commission on the Work of its FiftyThird Session' (2001) UN Doc A/56/10 (ARSIWA), art 1. 
partaking in activities in contravention of the rules limiting the use of natural resources in occupied territories may also result in the international criminal liability of individuals. ${ }^{235}$

\subsection{Direct State Responsibility of the Occupying Power}

International State responsibility is relevant to occupations and any violations of IHL governing such situations. ${ }^{236}$ In its Namibia Advisory Opinion (Namibia), the International Court of Justice (ICJ) specified that '[p]hysical control of a territory [...] is the basis of State liability for acts affecting other States. ${ }^{237}$ Thus, a State will be internationally responsible for wrongful acts of its organs, ${ }^{238}$ ranging from military commanders to state ministers, which violate the law of occupation governing natural resource use, ${ }^{239}$ such as exploitation benefitting the occupant's home economy. Such actions, including plundering of natural resources in an occupied territory, arguably also constitute pillage which applies to any appropriation of property not for military purposes. ${ }^{240}$ Pillage in relation to natural resources constitutes unlawful appropriation of resources for personal gain and is prohibited. ${ }^{241}$ Should an occupant exercise effective control over individuals or entities which are not de jure State organs, their wrongful acts can also be attributed to the occupant, rendering it responsible therefor. ${ }^{242}$ This could be the case if a natural gas exploration company subject to Turkey's directions and instructions violates the restrictions on the use of Northern Cyprus' natural resources. The Hague Regulations and Geneva Conventions were aimed at creating inter-State obligations rather than establishing individually enforceable rights for individuals. ${ }^{243}$ Accordingly, a State's breach of the restrictions on natural resource exploitation as aforesaid, through excessive exploitation or exploitation not benefiting the local population by its de jure or de facto organs, could be invoked to hold it accountable. ${ }^{244}$

Specifically in regard to the Geneva Conventions, the ICJ has emphasised that Article 1 of GCIV obliges parties to 'undertake to respect and to ensure

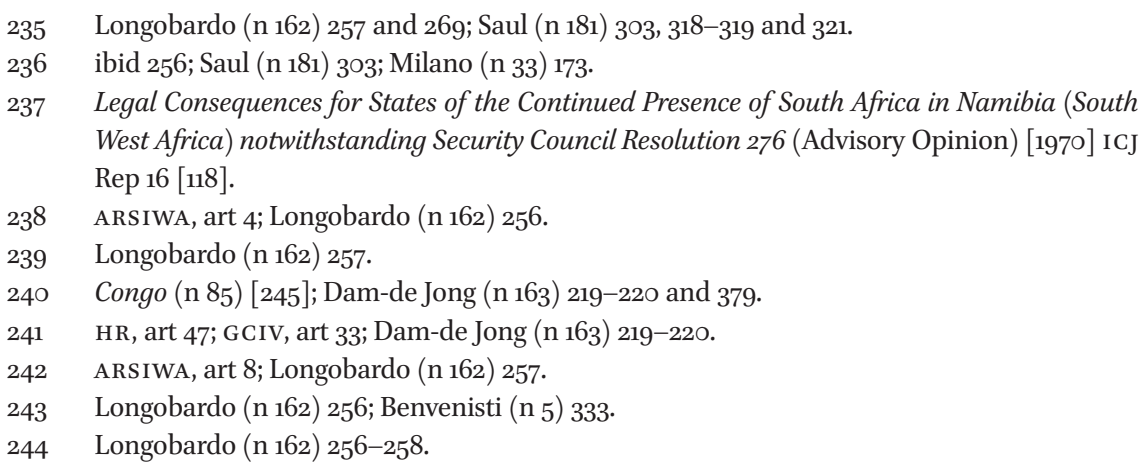


respect for the present Convention in all circumstances. ${ }^{245}$ Accordingly, State-parties are required to ensure compliance, even if they are not involved in the relevant conflict. ${ }^{246}$ In light thereof, any State-party could demand compliance by Turkey with its obligations under GCIV, including the prohibition of pillage under Article 33 and the prohibition of transfer of its nationals to the occupied territory under Article 49(6). Turkey would thus be obliged to cease its violations, guarantee non-repetition, and make reparations. ${ }^{247}$ Apart from ensuring accountability in international courts, there remains the option of instituting proceedings in domestic courts, ${ }^{248}$ including those functioning in the occupied territory, ${ }^{249}$ like that of the 'TRNC'. 250

\subsection{Occupying Power's Responsibility to Prevent Violations}

In addition to responsibility for their own violations, occupants also have the obligation to prevent violations by other actors who are not under their effective control, ${ }^{251}$ such as other States, armed groups, ${ }^{252}$ or private entities. Such obligation was confirmed to exist by the ICJ which held that a State must prevent other actors from plundering natural resources in the occupied territory. ${ }^{253}$ Under Article 43 of the Hague Regulations, the occupant is duty-bound to restore and maintain civil life, ${ }^{254}$ therefore, it must prevent illegal resource exploitation by third parties as part of this obligation. ${ }^{255}$ Any failure to comply with this obligation of due diligence will result in the activation of the occupant's international responsibility. ${ }^{256}$

\subsection{Responsibility of Third States and International Organisations}

Although the responsibility of the occupying power may be the most relevant, the obligations and consequent responsibility of third States and international organisations in dealing with natural resources in occupied territories are also important to consider. ${ }^{257}$

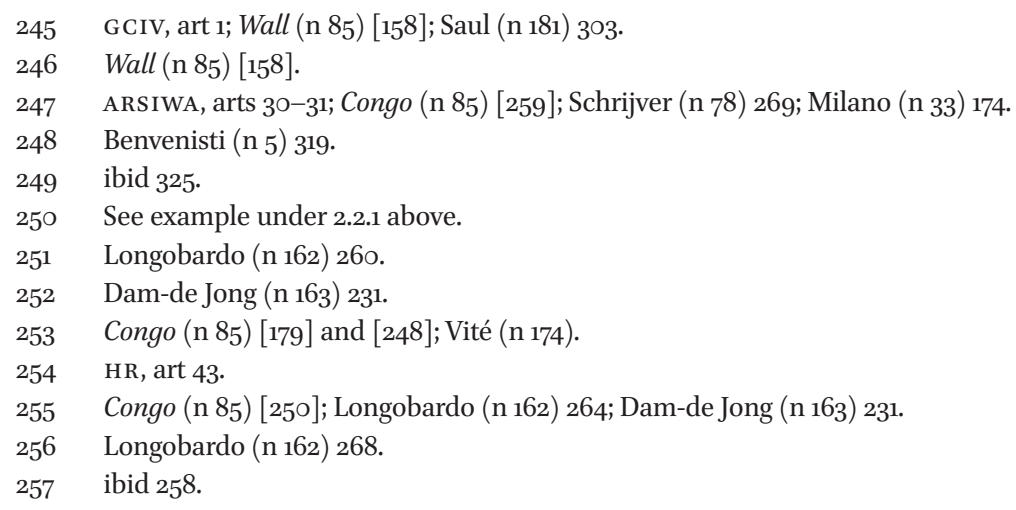




\subsubsection{Obligation of Non-Recognition}

In a situation of illegality, such as an illegal occupation or annexation resulting from illegitimate use of force, third States and international organisations have an obligation of non-recognition. ${ }^{258}$ Therefore, they may not recognise such situation and must refrain from acting in any way which would assist in the continuation thereof. ${ }^{259}$ Thus, such actors are prohibited from concluding agreements with an illegally occupying power, ${ }^{260}$ like Turkey, should such agreement constitute explicit or implicit recognition of the unlawful territorial annexation. ${ }^{261}$

Notwithstanding, in light of the ruling in Namibia, the duty of non-recognition does not include non-recognition of all activities of the occupying power. $^{262}$ The ICJ stated therein that non-recognition of an illegal territorial administration should not deprive the local population of benefits which could accrue to it as a result of international cooperation. ${ }^{263}$ Therefore, the duty of non-recognition is limited to dealings with the occupied territory which would place the population at a disadvantage, ${ }^{264}$ and thus prohibits cooperation which furthers the occupant's own economic, political, or other interests. Nevertheless, the effects of any agreement or arrangement which does indeed benefit the local population may not extend beyond the end of the occupation. ${ }^{265}$

In line with Namibia, the case of Cyprus $v$ Turkey before the ECtHR is particularly relevant. ${ }^{266}$ The ECtHR held therein that one cannot ignore all acts of de facto authorities like the ' $\mathrm{TRNC}$ ' which hold powers of administration in the relevant territory. ${ }^{267}$ 'Life goes on in the territory concerned for its inhabitants' and therefore, the interests of the inhabitants must be protected, including their rights to seek judicial redress. ${ }^{268}$ However, the ECtHR stressed that this

$25^{2} \quad$ Wall (n 85) [159]; Wrange (n 55) 10; Hummelbrunner (n 223) 781; ARsiWA, art 41; ILC, 'Draft Articles on the Responsibility of International Organisations' in 'Report of the International Law Commission on the Work of its Sixty-Third Session' (2011) UN Doc A/66/10 (ARIO), art 42.

259 Wall (n 85) [159]; Wrange (n 55) 10; Smith (n 129) 131-132.

26o Benvenisti ( $\left.\mathrm{n}_{5}\right) 85$.

261 Wrange (n 55) 10.

$262 \quad$ Namibia (n 237) [125]; ibid 10-11.

$263 \quad$ Namibia (n 237) [125].

264 Benvenisti (n 5) 85; Milano (n 33) 151.

265 Singer (n 67) 278; Benvenisti (n 5) 86.

266 Cyprus (n 106).

267 ibid [98]; Akgün (n 110) 15.

268 Cyprus (n 106) [96]; Milano (n 33) 147. 
would not result in the legitimisation of the 'TRNC'. ${ }^{269}$ This judgement diverges from the earlier judgement in Loizidou wherein the ECtHR rejected the notion of the 'TRNC' as a de facto authority. ${ }^{270}$ Notwithstanding, in order to ensure that the local population is not legally disadvantaged by such blanket non-recognition, it is clearly necessary to continue relations with de facto administrations for such population's benefit. ${ }^{271}$ The aforementioned judgements indicate how actions of occupying powers may be legally scrutinised through regional human rights enforcement mechanisms. ${ }^{272}$

\subsubsection{Economic Dealings with Occupied Territories}

Linked to non-recognition is the issue of economic dealings with an illegally occupying power or trade in respect of the occupied territory, and whether such dealings violate the duty of non-recognition implicitly. A number of cases regarding the EU's economic dealings with occupied Western Sahara, Palestine and Northern Cyprus illustrate the difficulties involved and the reluctance of the Court of Justice of the European Union (CJEU) to directly apply the international duty of non-recognition..$^{273}$

In Anastasiou, the CJEU dealt with movement and phytosanitary certificates issued by the 'TRNC'.274 It held that the EU and its members could not rely thereon since they had not been issued by the recognised Republic of Cyprus. ${ }^{275}$ However, the CJEU refrained from basing its findings on the duty of non-recognition stemming from the UN Security Council resolutions condemning the occupation by Turkey, ${ }^{276}$ and focused rather on maintaining uniform application of EU trade laws. ${ }^{277}$ In 2010, the CJEU encountered the case of Brita, relating to the territorial scope of the EU-Israel Association Agreement. ${ }^{278}$ The Court held that the agreement's territorial scope was implicitly restricted to

\footnotetext{
269 Cyprus (n 106) [92].

$270 \quad$ Loizidou (n 1) [44]; Akgün (n 110) 13; Milano (n 33) 143.

$271 \quad$ Milano (n 33) 151.

272 Benvenisti (n 5$) 319$.

273 Hummelbrunner (n 223) 787; Eva Kassoti, 'Between Sollen and Sein: The cJEu's reliance on international law in the interpretation of economic agreements covering occupied territories' (2020) 33 LJIL 371, 371-372.

274 Case C-432/92 The Queen v Minister of Agriculture, Fisheries and Food, Ex Parte Anastasiou [1994] ECR I-3087, [15]-[16]; Kassoti (n 273) 372.

$275 \quad$ Anastasiou (n 274) [40] and [67]; Kassoti (n 273) 373.

$276 \quad$ Kassoti (n 273) 373 .

277 Anastasiou (n 274) [54]-[56]; Hummelbrunner (n 223) 784; Kontorovich (n 215) 622.

278 Case C-386/o8 Firma Brita GmbH v Hauptzollamt Hamburg-Hafen [2010] ECR I-1289, [1]$[2]$ and [38].
} 
exclude the West Bank, ${ }^{279}$ but failed to address Israel's status as occupant or the EU's duty of non-recognition. ${ }^{280}$

The cases of Front Polisario and Western Sahara Campaign UK dealt with the lawfulness of EU-Morocco agricultural and fisheries agreements relating to occupied Western Sahara. ${ }^{281}$ The CJEU held that these agreements could not cover Western Saharan territory due to the EU's international law obligation to respect the principle of self-determination of the indigenous Sahrawi people. ${ }^{282}$ The CJEU viewed the EU as not being capable of breaching international law. This argument seems to be devoid of logic and neglects the reality that the agreements were in fact applied to Western Sahara's maritime areas. ${ }^{283}$ The CJEU similarly refrained from directly pronouncing on the EU's duty of non-recognition or the status of Western Sahara as illegally occupied, ${ }^{284}$ and based its decisions predominantly on the principle of self-determination. ${ }^{285}$

Finally, the recent case of Psagot dealt with goods originating from Israeli settlements in Palestine. ${ }^{286}$ This case followed the issue of an Interpretive Notice by the European Commission which connected the specification of a product's origin in the occupied territory with the obligation of non-recognition. ${ }^{287}$ It has been argued that this Interpretive Notice gave effect to the EU's duty of non-recognition under Article 42(2) of the ILC Draft Articles on the Responsibility of International Organisations. ${ }^{288}$ Notwithstanding, the CJEU again refrained from grounding its judgement on the duty of non-recognition and held that the obligation to indicate the product's origin stemmed from EU consumer legislation as interpreted according to international law. ${ }^{289}$

\footnotetext{
$279 \quad$ Brita (n 278) [52]-[53].

280 Hummelbrunner (n 223) 784-785; Kassoti (n 273) 374.

281 Case C-104/16 P Council v Front Polisario [2016] ECLI:EU:C:2016:973; Case C-266/16 Western Sahara Campaign UK v Commissioners [2018] ECLI:EU:C:2018:118; On Western Sahara's status as occupied see Kassoti (n 273) 374-376; Saul (n 181) 304-316; Wrange (n 55) 13 and 15 .

282 Front Polisario (n 281) [123]; Western Sahara Campaign UK (n 281) [63] and [71].

283 Kassoti (n 273) 384 and 388; Wrange (n 55) 3.

284 Wrange (n 55) 20.

285 Kassoti (n 273) 379.

286 Case C-363/18 Organisation Juive Européenne and Vignoble Psagot Ltd v Ministre de l'Économie et des Finances [2019] ECLI:EU:C:2019:954 [2].

287 European Commission, 'Interpretive Notice on indication of origin of goods from the territories occupied by Israel since June 1967' (11 November 2016) C (2015) 7834 final [2]; Cedric Ryngaert, 'Indications of Settlement Provenance and the Duty of Non-Recognition under International Law' (2019) 4 European Papers 791, 791.

288 ARIO, art 42(2); Ryngaert (n 287) 792.

$289 \quad$ Psagot (n 286) [35], [48] and [58]; Ryngaert (n 287) 793; Hummelbrunner (n 223) 786.
} 
Therefore, it remains uncertain whether third States and organisations may conclude trade agreements pertaining to occupied territories. Despite the obligation detailed in Namibia not to enter 'into economic and other forms of relationship or dealings' with an occupant, ${ }^{290}$ scholars disagree as to whether such dealings amount to implicit recognition and are thus prohibited. ${ }^{291}$ The Republic of Cyprus' position that a trade agreement between the EU and Northern Cyprus would result in tacit recognition of the 'TRNC' led to the agreement's abandonment. ${ }^{292}$ However, the CJEU, although given the opportunity, has remained unhelpful by avoiding the recognition of such a duty on the EU or its member States. ${ }^{293}$

\section{$5 \quad$ The Effect of Prolonged Occupation}

Modern-day occupations tend to extend for many years. ${ }^{294}$ Such prolonged occupations exacerbate the tension between the duty to maintain existing laws and institutions and the need to ensure the socio-economic development of the local inhabitants. ${ }^{295}$ The question arises whether granting an occupant more leeway would be appropriate in such circumstances, ${ }^{296}$ and whether an occupant should be entitled to take more advantage of natural resources on the ground that 'life must go on'.

This Section will discuss the impact of prolonged occupations on the application of the law of occupation generally and specifically relating to natural resource exploitation. Furthermore, it will detail the unique risks involved in regard to the potential entrenchment of the occupant's authority. Finally, it will conclude with arguing whether or not the law of occupation remains apt in governing prolonged occupations.

\subsection{Prolonged Occupations in General}

As discussed above, the law of occupation aims at regulating temporary situations wherein the occupant is granted the power of administration in

\footnotetext{
$290 \quad$ Namibia (n 237) [124].

$291 \quad$ Ryngaert (n 287) 796; Kontorovich (n 215) 634.

292 Dimitris Bouris and George Kyris, 'Europeanisation, Sovereignty and Contested States: The EU in Northern Cyprus and Palestine' (2017) 19 The British Journal of Politics and International Relations 755,76 o.

293 Hummelbrunner (n 223) 787; Kassoti (n 273) 388.

294 Benvenisti (n 5 ) 76.

295 ICRC (n 4) 73; Koutroulis (n 31) 177-178; Silingardi (n 116) 7 .

$296 \quad$ Koutroulis (n 31) 176.
} 
anticipation of the ousted sovereign's return. ${ }^{297}$ This reflects the intention of the drafters of the Hague Regulations and Geneva Conventions. ${ }^{298}$ The occupant is precluded from introducing changes in the occupied territory having an effect after the occupation ends, ${ }^{299}$ including extensive administrative reforms and new measures for economic development. ${ }^{300}$ However, when an occupation stretches for decades, the threat of the population's socio-economic stagnation increases and reforms become necessary. ${ }^{301}$ Dinstein, referring to the occupation of Palestine, has appropriately stated that '[i]t would simply be inconceivable for the legal system in Israel's occupied territories to have remained frozen in a time capsule. ${ }^{302}$

Despite the intention of its drafters, the Hague Regulations do not place any limits on the duration of occupations. ${ }^{303}$ However, Article 6(3) of GCIV provides as follows:

In the case of occupied territory, the application of the present Convention shall cease one year after the general close of military operations; however, the Occupying Power shall be bound, for the duration of the occupation, to the extent that such Power exercises the functions of government in such territory, by the provisions of the following Articles of the present Convention: 1 to $12,27,29$ to $34,47,49,51,52,53,59,61$ to $77,143 .{ }^{304}$

Accordingly, nine provisions in Part III of GCIV cease to apply to an occupation one year after the 'general close of military operations'. ${ }^{305}$ Theoretically, this decreases the protection afforded to civilians, which clearly contradicts the object and purpose of GCIV. ${ }^{306}$ Furthermore, it has been argued that this provision has been abrogated, ${ }^{307}$ although it was applied in the

Gross (n 49) 29; Yutaka Arai-Takahashi, 'Unearthing the Problematic Terrain of Prolonged Occupation' (2019) 52 Israel Law Review 125, 132; David Hughes, 'Moving from Management to Termination: A Case Study of Prolonged Occupation' (2018) 44 Brooklyn Journal of International Law 109, 113 .

298 Arai-Takahashi (n 297) 158; ICRC (n 4).

299 Spoerri (n 43) 196-197.

$300 \quad$ Hughes (n 297) 122.

301 Gross (n 49) 29; Arai-Takahashi (n 297) 145; ICRC (n 4); Regarding Northern Cyprus' underdevelopment see Bouris and Kyris (n 292) 766.

302 Dinstein (n 81).

303 Koutroulis (n 31) 172; Arai-Takahashi (n 297) 152.

304 GCIV, art 6(3) (emphasis added).

305 Gross (n 49) 32; Arai-Takahashi (n 297) 136.

306 Gross (n 49) 32.

307 Koutroulis $\left(\mathrm{n}_{31}\right) 173$. 
ICJ's Construction of a Wall in the Occupied Palestinian Territory Advisory Opinion. ${ }^{308}$ Notwithstanding, this provision has by now been superseded by Article 3 (b) AP I which specifies that '[...] the application of the Conventions and of this Protocol shall cease, [...] in the case of occupied territories, on the termination of the occupation.' ${ }^{309}$ Therefore, GCIV applies until the factual situation of occupation ends. ${ }^{310}$ At the time of writing, only 174 States have ratified AP I, excluding Turkey, ${ }^{311}$ however, some contend that Article $3(\mathrm{~b})$ has attained customary international law status, ${ }^{312}$ although this view is not universally shared. ${ }^{313}$ Irrespective thereof, Article 6(3) of GCIV is viewed as having been drafted with the post-Second World War occupations in mind, which envisaged the gradual transfer of the occupants' authority to local authorities. ${ }^{314}$ Furthermore, it has been submitted that the lessening of protection for the local population could never have been intended. ${ }^{315}$ Thus, considering later legal developments and modern-day practice of prolonged occupations which necessitate an increase in the occupant's responsibilities rather than a decrease, the aforementioned one-year limit can be considered to have become irrelevant. ${ }^{316}$

Consequently, the law of occupation continues to apply irrespective of the duration of an occupation, ${ }^{317}$ which can, theoretically, continue indefinitely. ${ }^{318}$ However, it has been argued that the unique problems created by prolonged occupations require a flexible application of the law of occupation and a greater degree of authority to be exercised by the occupant to better manage the situation. ${ }^{319}$ In such cases, it has been contended that 'serious modifications may [...] become indispensable. ${ }^{320}$ This could permit the occupant to implement broader initiatives, including the conclusion of treaties, ${ }^{321}$ to ensure that the

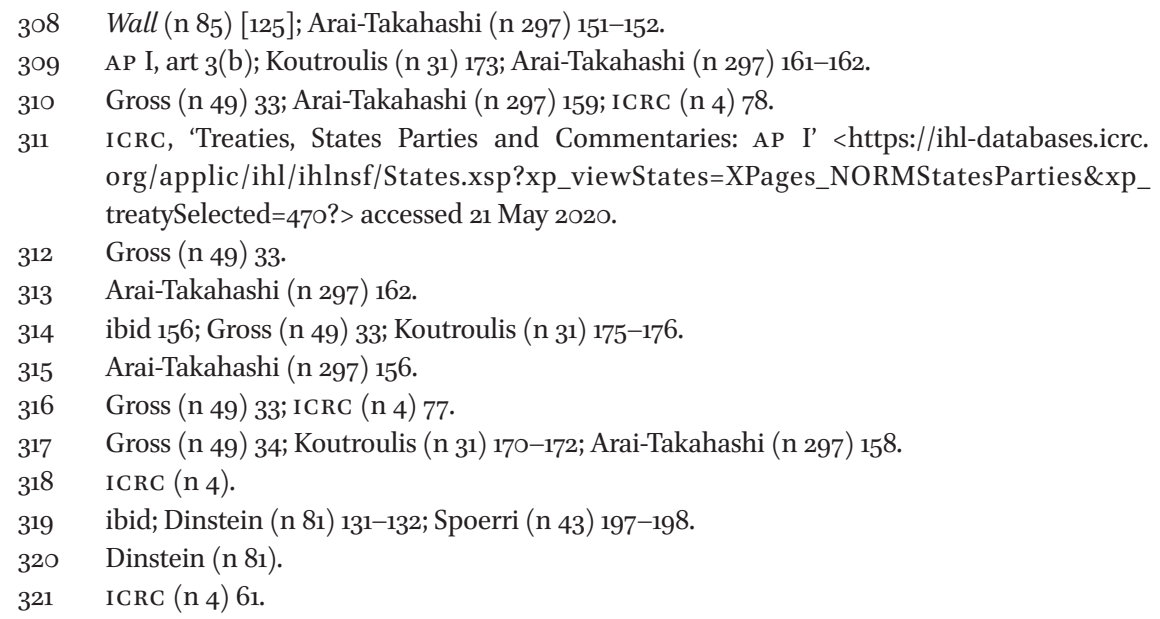


local population can develop. ${ }^{322}$ Accordingly, when determining whether an occupant has exceeded its powers, the duration of the occupation would be a relevant factor for consideration. ${ }^{323}$

This approach was followed by the Israeli Supreme Court in relation to the prolonged occupation of Palestine, ${ }^{324}$ which represents the only prolonged occupation where the occupying power has acknowledged its status as such. ${ }^{325}$ In Jamiat Ascan, the Court dealt with a property related conflict resulting from a highway infrastructure project to be implemented by Israel in the occupied territory. ${ }^{326}$ The petitioners argued that Israel could not proceed with the project due to its permanent effects which would continue past the end of the occupation, which project would benefit only Israeli interests. ${ }^{327}$ The Court based its judgement on Article 43 of the Hague Regulations and the need to balance the occupant's and the local population's interests. ${ }^{328}$ It found that certain measures not permitted during a short occupation may be permitted during a prolonged occupation. ${ }^{329}$ Thus, the occupant must ensure that infrastructure investments are made for the long-term benefit of the population. ${ }^{330}$ The Court referred to Electricity Company for Jerusalem wherein it held that the provision by an Israeli company of electricity to Hebron in the West Bank did not contravene Article 43, as it fulfilled the occupant's duty to ensure the population's economic welfare. ${ }^{331}$ Notwithstanding, the Court specified that the occupant's authority remained restricted and could not cause 'a substantive change in the fundamental institutions', specifically referring to the occupant's usufructuary obligations relating to immovable property. ${ }^{332}$

Although one should be wary in relying on the jurisprudence of one domestic system which some consider to be incorrect, ${ }^{333}$ the lack of jurisprudence on

\footnotetext{
$322 \quad$ ibid 74; Koutroulis (n 31) 177; Arai-Takahashi (n 63) 68.

323 Koutroulis (n 31) 179; Longobardo (n 39) 53 .

324 Dinstein (n 81); Longobardo (n 39) 52; Hughes (n 297) 112.

325 Koutroulis (n 31$)$.

326 HCJ 393/82 Jamiat Ascan et al $v$ IDF Commander in Judea and Samaria et al 37(4) PD 785 (1983) unofficial translation available at <http://www.hamoked.org/items/16o_eng.pdf> accessed 10 June 2020; also discussed in ibid 179-183 and Dinstein (n 81) 129-131. Jamiat Ascan (n 326) [8]; Dinstein (n 81) 129; Hughes (n 297) 141.

328 Jami'at Ascan (n 326) [12] and [29]; Dinstein (n 81) 129; Hughes (n 297) 142.

329 Jamiat Ascan (n 326) [22]; Dinstein (n 81) 130.

330 Jamiat Ascan (n 326) [27]; Dinstein (n 81) 130; Hughes (n 297) 143.

331 HCJ 256/72 Electricity Company for Jerusalem District v Minister of Defence et al 27(1) PD 124 (1972) 138 (only available in Hebrew), as referred to in Jamiat Ascan (n 326) [27]; Dinstein (n 81) 130; Gross (n 49) 46-47. 
this topic is evident. ${ }^{334}$ These cases indicate that the interpretation of Article 43 of the Hague Regulations can and even must be widened during prolonged occupations, ${ }^{335}$ provided this is to ensure provision for the local population, ${ }^{336}$ and that the line between military government and national government is not crossed. ${ }^{337}$ However, it is submitted that in reality it is difficult to draw such line accurately.

\subsection{Effect of the Prolonged Nature of an Occupation on Natural Resource Exploitation}

Particularly regarding natural resource exploitation, the widening of authority due to the occupation's prolonged nature could entitle an occupant to take more advantage of resources than what Article 55 of the Hague Regulations permits. Specifically, it could permit engagement in new development of resources which were not being exploited prior to the occupation, such as natural gas off the coast of Northern Cyprus.

In Yesh Din, the Israeli Supreme Court dealt with the exploitation of quarries by Israel in the occupied West Bank. ${ }^{338}$ The petitioner argued that Israel was not entitled to continue its quarrying activities or open new quarries as this contravened Articles 43 and 55 of the Hague Regulations. ${ }^{339}$ Israel contended that its actions were necessary due to the prolonged nature of the occupation. ${ }^{340}$ The Court agreed therewith and held that the unique nature of the occupation was relevant, especially considering the economic development needs of the population. ${ }^{341}$ However, the Court seemed to exclude the possibility of opening new quarries, ${ }^{342}$ in line with the ruling in Jamiat Ascan regarding the restriction on institutional changes and the principle of usufruct. Accordingly, although an occupant's additional powers could theoretically justify expanded resource development for purposes of the population's welfare, it appears that the development of newly discovered resources would remain prohibited.

\footnotetext{
334 Koutroulis (n 31) 171-172 and 205.

335 Dinstein (n 81) 131-132.

$336 \quad$ ICRC (n 4).

337 Koutroulis (n 31) 183 and 185-186.

338 HCJ 2164/og Yesh Din v Commander of IDF Forces in Judea and Samaria et al (26 December 2011) unofficial translation available at <http://www.hamoked.org/images/psak.pdf> accessed 10 June 2020; also discussed in ibid 183-186 and Hughes (n 297) 135-136.

339 Yesh Din (n 338) [3]; Koutroulis (n 31) 183.

$340 \quad$ Yesh Din (n 338) [9]; Koutroulis (n 31) 183.

$341 \quad$ Yesh Din (n 338) [10]; Koutroulis (n 31) 184; Hughes (n 297) 135-136.

342 Yesh Din (n 338) [12]-[13]; Koutroulis (n 31) 184.
} 


\subsection{Risk of Entrenchment of Authority and De Facto Annexation}

Although enabling an occupant to introduce wider ranging administrative measures may ensure the necessary socio-economic development of the local population, there are potential negative consequences, ${ }^{343}$ including edging towards unjustifiable 'transformative occupation. ${ }^{344}$ The extension of authority to better manage the occupied territory brings about the legitimisation of the occupant's actions which are otherwise illegal. ${ }^{345}$ This can cause the entrenchment of the occupant's authority which can further result in the de facto annexation of the territory. ${ }^{346}$

Accommodating the increased needs of the local population enables the occupying power to benefit from its position under a humanitarian guise. ${ }^{347}$ Due to the difficulty of establishing occupants' true intentions and the lack of monitoring mechanisms, occupants can further their economic, political, and strategic interests by relying on the prolonged nature of the occupation and resulting wider administrative powers. ${ }^{348}$ This can be illustrated by Electricity Company for Jerusalem, wherein the needs of the Israeli settlers in Kiryat Arba were also found to be relevant to the provision of electricity to the West Bank. ${ }^{349}$ Civilians settlers transferred to an occupied territory also have needs, irrespective of such settlements being prohibited. ${ }^{350}$ However, should this become a precedent, it could render legitimate Turkey's exploitation of the natural resources of Northern Cyprus for the benefit of the Turkish settlers. Furthermore, such exploitation could increase the economic incentives for Turkey to remain in occupation. ${ }^{351}$ This has been experienced in regard to Morocco's trade in the natural resources of Western Sahara which has created 'the appearance of a viable annexation' by directing revenue to the local population' which mainly consists of Moroccan settlers. ${ }^{352}$

The incentives to continue an occupation can be strengthened through economic cooperation with third States, international organisations and private

\footnotetext{
343 Gross (n 49) 50.

344 ibid 42; Spoerri (n 43) 196.

345 Arai-Takahashi (n 297) 167; Hughes (n 297) 125-126.

346 Koutroulis (n 31) 182 and 205.

347 Gross (n 49) 29 and 38; One way to ensure the local population is benefitted is to require the occupant to consider the will of the population when making decisions: ICRC ( $\mathrm{n} 4$ ) $75^{-76 .}$

348 Gross (n 49) 47 and 5o; ICRC (n 4) 73-74.

349 Electricity Company (n 331) 138 as referred to in Hughes (n 297) 144-145; Gross (n 49) 47.

350 Hughes (n 297) 111.

351 See discussion in ICRC (n 4) 73 .

$35^{2} \quad$ Smith (n 210) 279 .
} 
companies, which in turn legitimises the occupant's activities. ${ }^{353}$ Furthermore, the recognition of the effects of certain acts of an occupant as a de facto authority, as in the abovementioned case of Cyprus $v$ Turkey, can further enable the occupant to maintain such authority, ${ }^{354}$ even though such recognition aims at ensuring that the local population is protected. Similarly, in Demopoulos, the ECtHR took into consideration the duration of the occupation when finding that the applicants' individual rights should not be negatively influenced by the prolonged political dispute. ${ }^{355}$ Furthermore, in Namibia, the ICJ preferred an approach which would not deprive Namibian citizens of the advantages of international cooperation. ${ }^{356}$ Notwithstanding, allowing such provisional administration evidently contributes to the entrenchment thereof. ${ }^{357}$

Hughes argues that such risks emanate from the prevalent non-normative management approach to prolonged occupations. ${ }^{358}$ This approach views occupations as simply factual situations, not attaching any consequences to occupants' real motives. ${ }^{359}$ Such approach proposes that prolonged occupations merely require the attribution of extended authority to the occupant so that it can manage the situation better to avoid developmental stagnation. ${ }^{360}$ However, such extension of authority effectively legitimises the otherwise theoretically illegal acts of the occupant and allows its authority to become entrenched. ${ }^{361}$ This, Hughes argues, has occurred in Palestine with the help of the Israeli Supreme Court. ${ }^{362}$ Gross similarly contends that illegal acts unavoidably become viewed as legitimate due to the prevailing view that occupation is 'neutral', unlike colonialism or conquest. ${ }^{363}$

Hughes consequently proposes a normative approach. ${ }^{364} \mathrm{He}$ argues that occupations become prolonged not only due to their duration, but also when the form of control changes to 'a quasi-permanent administrative relationship. ${ }^{365}$ Therefore, when an occupying power can no longer genuinely base its occupation on temporary necessity or on humanitarian protection, it should

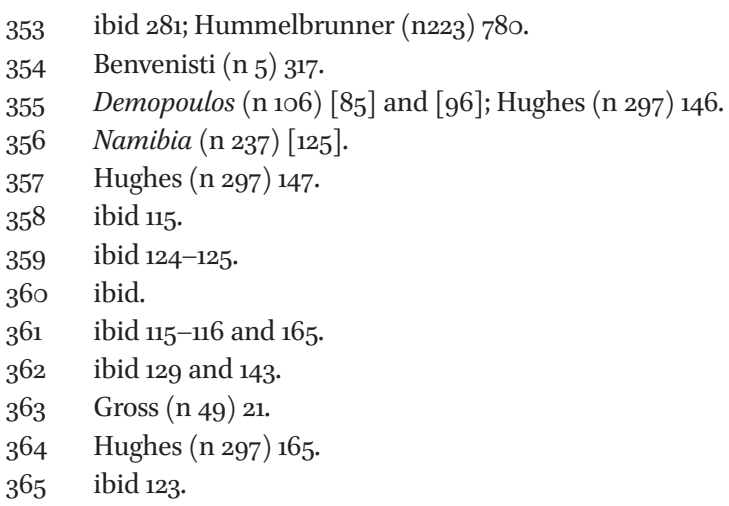


be placed under a good faith obligation to terminate the occupation, instead of granting it extended powers which perpetuate the occupation. ${ }^{366}$ This coincides with the purpose of the law of occupation which is founded on temporality. ${ }^{367}$ Thus, it is submitted that the law of occupation, although restrictive, remains relevant to prolonged occupations, ${ }^{368}$ precisely in order to prevent them.

The law of occupation grants rights and imposes duties on an occupying power to administer the occupied territory. This is in order to restore and maintain public order, provide for the occupying forces, and protect and provide for the local population, while maintaining, as far as possible, existing laws and institutions. This legal regime applies to all situations classified as occupations under Article 42 of the Hague Regulations and such application is not dependent on the legality of the manner in which the occupant gained control over the territory. Furthermore, the occupant's alleged motives, however laudable, and any denial of the state of occupation, have no bearing on the legal state of affairs. Accordingly, an occupant is bound to comply with the Hague Regulations and GCIV, including all provisions regulating the exploitation of natural resources. Furthermore, should an occupant exercise sufficient control over the maritime areas abutting the occupied territory, including the territorial waters, EEZ and continental shelf, such areas will also be considered occupied.

In consequence of Turkey's continued military presence in Northern Cyprus, it is safe to conclude that Northern Cyprus is occupied despite the illegality of Turkey's invasion, its alleged purpose of protecting Turkish Cypriot interests, or its denial of its status as occupant. Furthermore, provided that Turkey's forces exercise effective control over the maritime areas adjacent to the coast of Northern Cyprus, Turkey can also be considered as occupying such areas, and thus obliged to follow those regulations applicable to natural resources found therein.

Article 55 of the Hague Regulations governs the use of unextracted publicly owned natural resources in the occupied territory, such as natural gas which

\footnotetext{
366 ibid 118 and 166.

367 ibid 118, 166 and $171-172$.

368 Although in Scobbie (n 164) 235-236, Scobbie argues that the provisions of the Hague Regulations regarding natural resources may be 'unwieldy and ill-adapted to the exigencies of a modern economy'.
} 
remains in situ. In terms thereof, an occupant is only entitled to exploit such resources within the confines of the principle of usufruct which prohibits their exhaustion. Furthermore, despite general agreement that non-renewable resources may continue to be exploited at reasonable levels, consensus lacks regarding whether the occupant may exploit newly discovered or untapped resources. Notwithstanding, any use of natural resources must be for the local population's benefit or to provide for the occupying forces and cannot further the occupant's own interests such as its domestic economic development or that of its transferred settlers.

Accordingly, it appears that Turkey would only be entitled to exploit natural gas found offshore subject to the aforementioned limitations imposed by the principle of usufruct. Furthermore, Turkey would not be permitted to exploit any natural gas to benefit its own economy or settlers, which makes justifying any such exploitation difficult as such settlers constitute the majority of the population of Northern Cyprus. Any such natural resource exploitation would only be permitted assuming that new resource development is indeed legitimate. The contravention of the aforementioned restrictions through exploration or drilling activities or the conclusion of trade agreements may entail the international responsibility of the occupant. Such activities may also render participating international organisations and third States liable due to the obligation of non-recognition of illegal situations.

The law of occupation has experienced renewed interest in relation to modern-day occupations. Particularly, its suitability to govern prolonged occupations has been questioned. Prolonged occupations reflect the trend of occupants claiming wider administrative powers which theoretically exceed those granted under, inter alia, Article 43 of the Hague Regulations and Article 64 of GCIV. However, the prevention of the local population's economic stagnation practically requires occupants to take additional steps to ensure development and effective management for such population's benefit. Accordingly, it has been argued that in prolonged occupations leeway must be given to allow occupants greater discretion in implementing wider ranging initiatives, including wider measures relating to natural resource exploitation. Nevertheless, the exploitation of newly discovered resources appears to remain beyond the scope thereof.

Notwithstanding, some risks are involved in this approach. Firstly, such approach is predominantly based on the historical precedent of the Israeli occupation of Palestine and domestic jurisprudence emanating therefrom. Secondly, granting extended powers to an occupant in the name of benefitting the local population effectively legitimises otherwise illegal conduct and enables the occupant to entrench its authority towards a state of permanence. 
This is particularly evident during occupations wherein the occupant has exploited natural resources, thus increasing the inventive to retain control. Accordingly, the view has been expressed that such extended authority should not be granted and when it becomes necessary to take additional measures the occupant should bear the duty to terminate the occupation. Consequently, it is argued that the law of occupation remains suitable to govern prolonged occupations in order to bring about their end. However, whether an occupant would comply and terminate the occupation is a separate issue. ${ }^{369}$

Accordingly, due to the extended character of the occupation of Northern Cyprus, one could argue that Turkey should be granted wider powers relating to its natural gas drilling and exploration activities in the maritime areas of Northern Cyprus. This would undoubtedly be dependent on whether such exploitation benefits the local population and whether one considers the exploitation of untapped natural gas lawful. However, proponents of a normative approach would argue that such extended powers should not be attributed as they perpetuate the occupation, which argument is indeed convincing. This approach allows the original intention of the drafters of the Hague Regulations and GCIV to remain relevant and the legal regime not to be discarded as wholly inappropriate by those favouring a new codification specifically catering for prolonged occupations. ${ }^{370}$

Irrespective of whether one views prolonged occupations as enabling or disabling for occupants, the law of occupation will not assist Turkey in its quest for Northern Cyprus' natural gas should it not recognise itself as occupying power. ${ }^{371}$ The onerous obligations involved have prevented modern-day occupants from acknowledging their status as such, and it seems unlikely that Turkey will do so in future. Accordingly, considering the historical ethnic tensions characterising the conflict between Greek and Turkish Cypriots, the solution which appears as the only probable way forward, in relation to the island's division in general and the issue of natural gas exploitation and potential revenue sharing, would be a negotiated settlement. ${ }^{372}$ Although seemingly simple, it has proven to be just the opposite considering the numerous attempts at settlement made over the decades and Turkey's alleged endeavours to break out as a regional energy power. ${ }^{373}$

369 Hughes (n 297) 161.

370 Silingardi (n 116) 7 .

371 See similar argument regarding Western Sahara in Saul (n 181) 320.

372 Benvenisti (n 5) 85 and $315-316$.

373 Kentas (n 26) 13-14. 


\section{Acknowledgements}

The author's contribution constitutes part of her Master's thesis, submitted in partial fulfillment of the requirements for the degree LL.M. Public International Law at Leiden University. The author wishes to thank Dr. Robert Heinsch for his valuable guidance and helpful suggestions. 